\title{
Evaluation of Risk Prioritization and Budget Allocation Methods for Pollution Prevention Activities
}

\author{
Jeff Daniels \\ Ed Jones \\ Alan Lamont \\ Tony Ladran \\ Jill Watz
}

January 1997

This is an informal rport intended primarily for internal or libatied external dibtribution. The oplnions and conclublems etated are thene of the auther and may or may net be theee of the Laboritory.

Work pexformed undex she aupices of the U.S. Department of Energy by the Lowrence Livernere National Laboratery under Contract W-7Los-Eng-e. 


\section{DISCLAMMER}

This document was prepered as an account of work sponsored by an azoncy of the United States Government. Neithe the United States Covernment nor the University of Criformin nor any of their

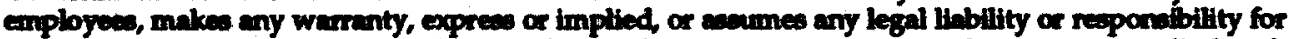
the eccurscy, completences, of useftiness of any information, apparatus, product, of process disclosed, or ropresents that ts use would not infinge pitvately owned right Reference hareln to any specific commercill product, proceses, of sorvice by trade name, tradennek, manufacturex, or otherwise, does not necesarily conetitute or imply its endorsement, recommendation, or fovoring by the United States Government of the Univeraity of California. The views and optnions of authors expreseed herein do not necesearly state or reflect those of the Unibed States Govemment or the University of California, and abll not be wed for advertiaing or product endorsement purposes.

This report has been reproduced directly from the best availsble copy.

Avallable to DOE and DOE contractors from the Oifice of Scientific and Technical Information P.O. Box 62, Onk Ridre, TN 37831

Prices aveilable from (615) 576-8101, FTS 626-8401

Aveileble to the public from the National Technical Information Service

U.S. Department of Commerce 5285 Port Royal Rd. Spingfield, VA 22161 


\section{Evaluation of \\ Risk Prioritization and Budget Allocation Methods for Pollution Prevention Activities}

January, 1997

Prepared for DOE Environmental Management Office of Pollution Prevention

Lawrence Livermore National Laboratory

Jeff Daniels

Ed Jones

Alan Lamont

Tony Ladran

Jill Watz 


\section{Table of Contents}

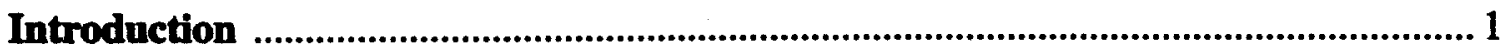

Section 1. MEM And RPM Scoring Systems for Pollution Prevention Activities and Proposed Fixes.................................................................................................... 2

Tools for Evaluationg Activities and Assisting in Budget Allocation Decisions ..... 3

Essential Characteristics of a Scoring and Ranking Procedure.................................... 4

Characteristics of Pollution Prevention Activities ...................................................... 5

Potential Problems with the MEM/RPM Framework that Can Affect Ranking

Pollution Prevention Activities .........................................................................................5

Structure of Activities Defined for the EM process Can Affect Ranking..................... 8

Proposed Changes ................................................................................................................. 9

Conclusions ..................................................................................................................... 12

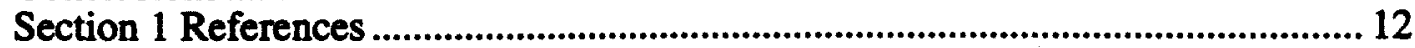

Section 2. Pollution Prevention Case Studies:

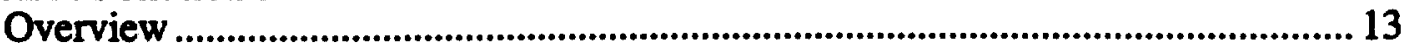

Risk Evaluation in the Absence of Full Risk Assessment............................................ 15

Hazard Screening and RPM Evaluation Method ........................................................... 17

Case Study 1: High Explosive Disposition ............................................................... 19

Case Study 2: Beneficial Reuse of LBL Shielding Blocks at Brookhaven................ 23

Case Study 3: Elimination of Photochemical Wastes at LBL...................................... 26

Case Study 4: Argonne Dry-Ice Pellet Decontamination System.............................. 29

Case Study 5: Electroplating Waste Minimization ...................................................... 32

Summary of Case Study Evaluation ................................................................................... 36

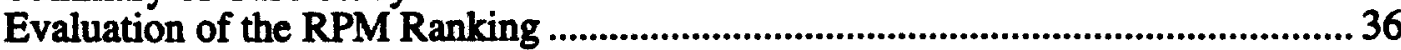

Net Risk Reduction ................................................................................................. 38

Pollution Prevention: Low Risk Benefit per RPM.................................................... 40

Alternative Cost Scale ..........................................................................................................4 41

Section 3. Outline of Recommended Traíning for Conducting RPM/MEM

Assessments.

Appendix A: Hazard Category Checklist...............................................................................A-1

Appendix B: Description of RPM Consequence Categories............................................. B-1 


\section{Introduction}

In evaluating the Environmental Management (EM) risk assessment/budget prioritization process, it was observed that typical DOE pollution prevention projects could not always be properly ranked because the activities the process is designed to capture are larger in size and scope than most pollution prevention activities. Because of their nature, many pollution prevention projects do not fall into the scale of activities evaluated under the present system. We conclude that inherent inconsistencies in the current system unintentionally eliminate smaller, valuable activities, which when appropriately ranked would often be competitive with other activities.

This study reviews the structure of two main risk prioritization/budget allocation methods developed by the DOE Risk-Based Priority Mode (RPM) and Management Evaluation Matrix (MEM). It identifies potential augmentations to the process that will address both risk reduction and cost-effective investment of finite resources for future EM activities.

The evaluation was performed in accordance with the EM Ten-Year Vision and Principles for site cleanup. The evaluation and recommendations in this report strive to reflect four key principles, namely to:

1. Eliminate the most urgent risks.

2. Reduce mortgage and support costs to make funds available for further risk reduction.

3. Protect worker health and safety.

4. Reduce the generation of wastes.

The recommendations and proposed actions are relevant to both general core EM activities and those considered discretionary, such as pollution prevention.

As part of the study, we evaluated five EM-funded pollution prevention case studies to determine their relative risk-reduction potential with respect to the conventional operation or process. The case studies were evaluated using a modified RPM approach to demonstrate how such projects score in each of the RPM risk categories.

Section 1 reviews the MEM and RPM methodologies and proposes several minor, but important, modifications that meet the major objectives of the EM ten-year plan.

Section 2 evaluates five pollution prevention projects in terms of a risk/hazard analysis that serves as an example of how risk parameters can be assessed in the absence of time and resources required to perform a more traditional risk assessment. Such an annotated assessment allows many projects and possible scenarios to be compared in terms of net risk reduction. It also allows the assessment team an opportunity to narrow the scope of activities, and perhaps to perform more in-depth studies on a few activities. Section 3 offers recommendations for deploying and improving the effectiveness of these risk assessment tools in the field. 


\section{Section 1. \\ MEM And RPM Scoring Systems \\ For Pollution Prevention Activities and Proposed Fixes}

The Management Evaluation Matrix (MEM), Risk Data Sheets (RDSs), and Risk-Based Priority Model (RPM) are tools developed by the Office of Environmental Management and by the Office of Environmental Safety and Health to evaluate the risk reduction afforded by their activities. A concern has been raised that some activities, such as pollution prevention, are not appropriately evaluated with these tools.

This report examines the evaluation processes based on the MEM and RPM to determine whether their structure could lead to situations in which pollution prevention activities would, in fact, not be given the appropriate priority. Because the RDS is primarily used as a form for reporting and documenting information used by the MEM and RPM, it is not considered to be a separate process in this discussion.

In this examination, some structural features of the processes were identified that would lead to inappropriate rankings of some types of activities. The Peer Review Committee of the Consortium for Risk Evaluation with Stakeholder Participation (CRESP) identified the same features in their report (CRESP 96) as possible shortcomings in the MEM process. We found that some of the characteristics of pollution prevention activities can exacerbate those problems, leading to lower evaluations for activities such as pollution prevention.

Overall, we believe the MEM and RPM processes have a sound basis and are useful. Although we and the CRESP report identify some concerns regarding MEM, we believe that these concerns can be addressed within the existing RPM framework. This section suggests certain changes that could be made to improve the process so that it addresses pollution prevention activities more appropriately. In Section 1, we:

- Describe background information on the evaluation tools that have been developed by EM to evaluate risk.

- Discuss the characteristics that an evaluation and budget-allocation process should have if it is to arrive at an efficient budget allocation. We take the position that an "appropriate" budget allocation is one that is "efficient" in a well defined sense.

- Examine the particular benefits of pollution prevention activities to determine whether or not those benefits are accounted for in the evaluation processes.

- Identify possible characteristics of the existing process that could lead to an inappropriate ranking and evaluation of pollution prevention activities, taking into account the characteristics of pollution prevention activities and the characteristics of an appropriate budget allocation.

- Suggest possible changes to the evaluation systems that can improve the way that pollution prevention activities are evaluated and compared to other activities. 


\section{Tools for Evaluating Activities and Assisting in Budget Allocation Decisions}

We focus on three of the tools that have been developed to provide a systematic framework for characterizing risks and ranking activities based on their potential for risk reduction. The Management Evaluation Matrix (MEM) defines categories and scales for scoring the risk impacts of activities. The Risk Data Sheets (RDSs) are forms used for recording risk information. The Risk-Based Priority Model (RPM) is a method for comparing and ranking activities based on the information recorded in the RDSs.

The MEM provides a systematic and formal method for characterizing the risks that arise from a given situation. MEM includes a set of categories of risk, addressing issues such as Public Safety and Health, Site Personnel Safety and Health, and Mission Impact, among others. An activity is characterized by specifying the level of impact in each category (e.g., for Public Safety and Health, two categories are "Immediate of eventual loss of life/permanent disability" and "Excessive exposure and/or injury"). MEM also describes the uncertainty by allowing the user to specify a likelihood for the specified level of impact (DOE, 1995).

MEM characterizes the risk in each category as high, medium, or low $(H, M, L)$ depending on the level of impact and its likelihood. MEM does not include comparisons between categories. It makes no statement that a Medium in "Site Personnel Safety and Health" is better than, worse than, or the same as a Medium in "Public Safety and Health." Consequently, there is no obvious way to produce an overall score for an activity or to compare activities based on their overall risk impact.

RDSs are used in the field to record the scores for various activities. The MEM scores for each category of impact are recorded for the situation before the activity begins and after it is competed. The risks during the activity are also recorded. In principle, the difference between the before and after scores is a measure of the reduction in risk due to the activity. However, we note (as does CRESP, p. 87) that the values produced are the letter designations $(\mathrm{H}, \mathrm{M}, \mathrm{L})$. There is no obvious way to subtract them or to combine scores across categories. Apparently, in actual practice, these values have been used in at least some cases to provide a rough ranking within a single category of risk (e.g., Site personnel safety and health).

The RPM allows comparisons and develops overall rankings (refer to U.S. DOE Project Management Prioritization Guide (DOE, 1996)). RPM uses a set of categories and impact levels that are nearly identical to those used by MEM. A numeric score is assigned to each level of each category of impact. The scores range from near 0 (very low risk) to 3,000 (very high risk). The score is multiplied by the likelihood value to arrive at a risk score. Thus, if a situation is almost certain to result in a public fatality, it receives a risk score of 3,000 . If there is 1 chance in 100 of a public fatality, the risk score is $3,000 \times 0.01=30$. The risk scores in each category are then summed to obtain an overall risk score for the situation. The risk scores before and after an activity is implemented are subtracted to produce the risk reduction from the activity. The activities can then be

\footnotetext{
${ }^{1}$ It might be assumed that an $\mathrm{H}$ in one category should be the same as an $\mathrm{H}$ in another category. However, the highest level in each category is assigned an $\mathrm{H}$ when the likelihood is in either the highest or next to highest category. Thus High, Medium, and Low ratings are assigned in the same way to all of the categories.
} 
ranked by their risk reduction scores. Once a ranking has been developed, the RPM provides a procedure for selecting activities to be funded. This procedure will be discussed in more detail later.

The scores used by RPM are a key part of the method. The scores represent value judgments about the relative importance, or desirability, of different levels of impact in each of the categories. Because they do represent value judgments, there is no objective method for assigning them. That is, one cannot say that a particular set of scores should be used. They must be elicited as value judgments from a person. Because such judgments are personal, the best that one can do in assigning scores is to ensure that they are internally consistent and that they correctly reflect the values of the person from whom they are elicited, for theory and methods of eliciting value judgments (Keeney, 1976) (von Winterfeldt, 1986).

In practice, a group of people often have similar value judgments, and it is often possible to find a set of scores that are generally acceptable to a group. In this case, we informally reviewed the scores used and made several comparisons to see if they generally agreed with judgments that our personnel might make. The scores seemed to fit our judgments reasonably well. We did not find deviations that were cause for immediate concern.

\section{Essential Characteristics of a Scoring and Ranking Procedure for Budget Allocations}

This report addresses the concern that pollution prevention activities are not evaluated and ranked "appropriately." To discuss that concern and to identify what changes we might propose, it is important to define what a scoring and ranking system should do and the basic features that it must have to accomplish its goal.

A budget allocation procedure should help an organization increase the benefit obtained for a given budget. This point was reiterated by the CRESP report (CRESP, p. 33). To do this effectively, the procedure must be designed from the ground up to gather the correct information and then process it in a way that allows the user to identify those activities that will maximize benefits and still be within a given budget. At a minimum, a process should include the following features:

- Identify an appropriate set of alternatives to be evaluated and compared. The set of alternatives should reflect the actual choices that are available to decision makers. Inefficient decisions can arise when an "alternative" is actually a bundle of possible actions, each of which could be decided on individually. When this occurs, actions that may not be justified on their own merits will be funded simply because they have been bundled together with more desirable actions.

- Describe the impact that each of the alternative activities has on all of the issues of concern in a clear, unambiguous way. The scoring framework (e.g., scoring categories and levels within the categories) should be detailed enough that individuals can provide consistent and comparable scores for different activities.

- Define a single, overall measure of benefits. The measure of benefit should include all of the issues that are relevant to a decision maker. In the EM process, these issues include public and on-site safety and health, mission impact, financial and budgetary concerns, environmental and safety concerns, and regulatory concerns.

- Compare activities on the basis of their benefit-cost ratio. Otherwise the procedure will not result in an optimal allocation of funds. Consequently, the process must collect and use information on the costs of activities. 
In the following discussion, we discuss the extent to which the tools meet these requirements and the potential distortions that might arise in evaluating pollution prevention activities when the requirements are not met.

\section{Characteristics of Pollution Prevention Activities}

The characteristics of pollution prevention activities themselves partly determine the extent to which they are appropriately evaluated. After examining various pollution prevention activities, our investigation indicates that they often do not have strong advantages in terms of concerns such as risk reduction, compliance, or mission impact. However, they often do have expected benefits in costs savings (e.g., mortgage reduction). In fact, it appears that they often have a net savings over their life cycles. If cost is often an advantage for pollution prevention activities, it follows that an evaluation system must evaluate cost appropriately.

The characteristics of pollution prevention activities are illustrated by several examples in Section 2. Candidate pollution prevention activities were identified that covered the range of typical applications of pollution prevention at several DOE sites. For each example, we identified the categories in the RPM where the activity was expected to make a useful contribution. The reasons that a contribution was deemed likely, or unlikely, are discussed in detail in Section 2.

Overall, these examples illustrate that pollution prevention activities often do not reduce the risk arising from immediate hazards (e.g., onsite or offsite safety and health) or from noncompliance with regulations. Most facilities are currently managed fairly well-they do not pose large health risks, and they are largely in compliance. Any improvements in immediate risk that could result from pollution prevention are small; thus, potential improvements in immediate risk and compliance are small. On the other hand, pollution prevention activities can often provide valuable improvements in the efficiency of operations. This is particularly true as we become more aware of, and are required to pay for, the costs of reducing environmental impacts from emissions and waste. Pollution prevention is one of the ways of achieving such efficiencies.

Such savings are significant and should be exploited. However, the advantages cannot be taken into account unless the evaluation system correctly includes all of the financial costs and benefits of a proposed activity. We find that the MEM/RPM framework does not account for the financial benefits of activities particularly well, leading to an undervaluing of pollution prevention activities.

\section{Potential Problems with the MEM/RPM Framework that Can Affect Ranking of Pollution Prevention Activities}

The MEM/RPM framework has been developed to assist managers in selecting activities for funding. It develops a score for each activity based on its evaluation in the RDS. The score is used to rank the activities and select the best ones for funding. Inefficient budget allocation can result from the way that the MEM and RPM processes include financial issues and from the procedures used in RPM for ranking the activities and selecting those for funding (recall that MEM does not include methods for determining an overall ranking of activities). The characteristics of pollution prevention activities make it likely that they would be undervalued and not funded when, in fact, it would be efficient to do so. 
The following sections outline the features of the MEM/RDS/RPM framework that can lead to inefficient budget allocations and the ways that pollution prevention activities are affected by these features.

\section{Insufincient Information is Collected About Financial Costs and Benefits}

The RDSs do not account for the net discounted cash flow of a proposed activity over its life. Financial considerations included in the MEM/RPM emphasize the extent to which there is the possibility that some large expenditure might be incurred without the activity (i.e., the activity results in an avoided cost). This is, of course, an important part of the financial considerations for an activity, but not the entire picture. The RDS does record information about the cost that must be invested to implement the activity, but the information is not included in the scoring. Furthermore, no discounting is used, which can be significant for comparing activities that will have costs and benefits in the future.

Costs are an essential part of the objectives of any government decision process and should be correctly included in the process. The Office of Management and Budget (OMB) has developed a set of guidelines for accounting for financial costs and benefits (OMB, 1992). These guidelines essentially specify that net discounted cash flow from a proposed activity should be used as part of funding decisions.

The CRESP report also emphasized that the discounted cash flow should be used to measure the financial impacts of an activity (commonly called "mortgage reduction"). The report points out that the 10-Year Plan Guidance Memorandum contains an attachment on Mortgage Reduction Guidance that should be incorporated in the process. This Guidance is consistent with the OMB guidelines.

The omission of accurate cost information could cause substantial distortions in funding decisions. Many DOE facilities actually have relatively small risks even in their current state. At many sites, the risk reduction from proposed activities will be small.

Consequently, the financial aspects of proposed activities may be the deciding factor among them. However, if the financial aspects are not properly accounted for, the results tend to be arbitrary and unrelated to the true value of the activities.

\section{Scales are Not Detailed Enough for Useful Comparisons}

The scales used to measure mortgage reduction (e.g., financial impact) only allow for two levels: savings greater than $\$ 25 \mathrm{M}$ (or greater than $\$ 1$ to $\$ 5 \mathrm{M}$ per year), and savings less than \$25M (or less than \$1M per year). This method does not allow enough resolution to score pollution prevention (such activities are often less than \$25M).

The description for the scoring category is also unclear. Although "operational efficiency" is mentioned, there is no real discussion to suggest that a careful accounting for the costs and savings over the life of the activity would be called for.

\section{Form of the Evaluation Function and Value Judgments Could Be Reviewed}

The RPM computes the overall evaluation as a weighted sum of scores in each category. The scores assigned to each level in a category represent value judgments about the relative importance of different levels within a category. Maximum values for the categories (which represent the highest risk values for the categories) represent the relative importance of one category compared to another. For example, in the Public Safety and Health category, the level "Immediate or eventual loss of life/permanent disability" is assigned a score of 3,000, "Excessive exposure and/or injury" is assigned a score of 300, and "Moderate to low level exposure" is assigned a score of 30. 
Value judgments are essential here. There is no objective way to specify that one category should have more or less weight than another. The value judgments can be clarified through formal procedures ${ }^{2}$. After reviewing some of the relative value judgments implied by the weights assigned in the RPM, we did not find obvious concerns, but this issue could be formally addressed and documented.

A weighted sum is often an appropriate way to construct a measure of benefit. However, in some circumstances a weighted sum will not adequately represent the preferences of a decision maker. ${ }^{3}$ Again, we did not find obvious concerns, but the choice of the form of the evaluation function could also be formally addressed and documented.

\section{Procedure for Allocating Funds Is Not Optimal}

The MEM and RDSs do not include an explicit method for ranking activities. The RPM is designed to provide a ranking and to allocate funds. The RPM can be used to compile and rank activities that are scored under the MEM/RDS process. However, since the RPM categories and scales are not identical in all cases, some small extensions would be required.

The RPM method ranks proposed activities in order of largest increase in benefits, regardless of cost. Activities with the largest benefits are funded until funds run out. This procedure is inefficient in the sense that it does not maximize the amount of benefit that can be obtained for a given budget. Some projects with large benefits but very large costs will be funded. However, other projects with smaller benefits and very small costs in relation to the benefits will be placed at the bottom of the list and not funded. This process will generally not yield the largest benefit for a limited budget.

For example, consider a process that generates a highly flammable waste stream that poses a significant risk of fire. Substantial risks to on-site personnel and the possibility of significant costs in the future would arise in the event of an accident and the material being ignited. Furthermore, suppose that two activities are proposed to reduce the risk. Activity A would install a fire-suppression system at a cost of \$1M. Activity B would change the process to eliminate the stream at a cost of \$500K. Under the RPM, the two activities would score about the same because they both would have about the same benefits. Both eliminate the safety risk to personnel, and both reduce the avoidable cost. The RPM does not account for the fact that one alternative is substantially cheaper than the other. A benefit-cost analysis would immediately show that Activity $B$ is the preferred option.

The guidance included with the RPM does recognize this possibility. It suggests that managers can override the procedure and move activities with large benefit/cost ratios to the top of the list. However, the process itself should directly do this. There is no reason to rely on an ad hoc procedure to ensure that activities with the largest benefit/cost ratios are funded first.

To allocate funds more efficiently, activities should be ranked according to their benefit/cost ratios. The best activity should be funded, down to the limit of the budget.

\footnotetext{
2 See Keeney and Raiffa or Edwands.

${ }^{3}$ Whether or not the weighted sum is appropriate for a given situation depends on the nature of the atributes being measures and the value judgments of the person responsible for making decisions. See Keeney and Raiffa, or Edwards for a discussion of the issues in developing evaluation functions.
} 


\section{Implications for Pollution Prevention}

The implications of the RDS/RPM process for pollution prevention activities can be summarized as follows:

- Net savings of pollution prevention activities are not accounted for clearly in the scoring method. They do not get credit for their contribution to financial savings.

- Pollution prevention tends to have net savings, but such activities compete against projects that have net costs. The fact that other projects have net cost is not counted against them (only the benefits are counted in their score).

- Because activities are ranked in order of benefits (and do not take costs into account), activities that have large benefits are ranked higher than activities with small benefits regardless of the cost. Pollution prevention activities tend to have small benefits and are ranked at the bottom, regardless of the overall benefit/cost ratio.

\section{Structure of Activities Defined for the EM Process Can Affect Ranking of Pollution Prevention Activities}

In addition to concerns about the internal structure of the MEM/RDS/RPM process, pollution prevention activities can be inappropriately evaluated in terms of the way that the activities have been defined and structured. An evaluation and decision tool should be applied to compare activities that are discretionary and are actually competing for resources. In the EM evaluation process, many of the activities that are compared are not discretionary; thus, it is not possible to make a useful comparison to activities that are discretionary. Furthermore, some smaller activities that might be discretionary are bundled into larger activities for evaluation. Thus, these smaller activities are never actually compared to pollution prevention activities.

The existing EM process uses RDSs to characterize the risk reduction due to each EM activity. The purpose of the process is to gather information about the risk impact of various EM activities to assist in making programmatic decisions. It is not intended to be the sole input for making such decisions.

The activities defined for evaluation are generally whole elements of the WBS, which are fundamentally accounting units. They group together large sets of activities related to some common function, such as site management or hazardous waste control. At some sites (perhaps all sites), activities that support pollution prevention are called out as separate WBS elements. The supporting activities help identify and evaluate opportunities for pollution prevention, but they do not necessarily fund implementation. Typically, the implementation of pollution prevention activities is included as possible actions within some of the other WBS evaluated elements.

Given the way that the activities have been structured and bundled, pollution prevention activities may not be evaluated appropriately. Pollution prevention activities tend to be small and are incremental improvements to existing processes. However, in the EM evaluation process, entire WBS elements that represent essential functions are scored on an all-or-nothing basis. Thus, the process evaluates the increment in risk that would result from elimination of an entire WBS element, such as Hazardous Waste Management or Continuity of Operations. The change in risk from elimination of entire WBS elementsespecially when ES\&H, Compliance, and Mission are included-is very large. In contrast, the change in risk resulting from pollution prevention activities does not appear to be as compelling. The results might differ substantially if small, incremental portions of the WBS elements were compared to proposed pollution prevention activities. 
The CRESP report calls this the "minsafe" issue. It points out that many of the WBS elements are essential functions that must be performed to some degree to provide a minimum level of safety at a site. The functions include "site-wide health and safety, surveillance and maintenance, security and safeguards programs, infrastructure programs, fire protection, emergency response, and a broad range of administrative and management functions including the personnel and support budget" (CRESP, p. 38). CRESP questions whether these elements should be scored and assessed in the same way that other discretionary activities are assessed. We agree that this should be reviewed.

The grouping of activities according to WBS elements can also be inappropriate for evaluating pollution prevention activities because of the breadth of many of the WBS elements. Some elements-even those that are part of the minsafe elements-include a wide range of activities. Some of these activities may be directly related to the safe operation of the site, whereas others may have little or nothing to do with safety. For example, CRESP points out that some minsafe programs include essential management functions, but they may also include activities such as laundry or food services (CRESP, p. 67).

The fact that pollution prevention activities do not provide for risk reduction as large as other WBS elements when scored by the current evaluation process should not be taken to mean that pollution prevention activities are not valuable. It simply indicates that, given a choice between pollution prevention and another entire element of EM operation, such as all of Hazardous Waste Management on the basis of risk reduction, then one would probably choose Hazardous Waste Management. The essential point is that the methodology does not compare activities that truly compete with each other.

\section{Proposed Changes}

With relatively few modifications, the existing process could be extended to address the issues discussed above. Here, we outline these modifications.

\section{Replace the Scale for Mortgage Reduction (Also Called "Avoidable Cost")}

The scale used for measuring the financial impact of an activity should be modified. The current wording is in terms of "avoidable costs," however, such costs are not well defined. Financial impact should be measured in terms of net discounted cost over the life of the activity. Several existing guides can be used to prepare such an analysis. The OMB Circular No. A-94 provides detailed guidance on basic methods and interest rates to be used. The "Total Cost Assessment Guidance Document" drafted by Lawrence Berkeley National Laboratory for the EM-77 office also describes how this can be done in the context of pollution prevention activities.

Costs can be evaluated in terms of either total costs or the change in cost from a baseline. It may be easier to evaluate pollution prevention activities using the change in cost from the current ("before") conditions. Thus, the before situation would represent a \$0 change. If the "after" situation is positive, then on a net discounted basis, the activity costs money. If the "after" situation has a negative change in discounted net costs, the activity saves money.

In the RPM, score values are assigned to risk impact ranging from 0 to 3,000 . High values indicate undesirable impacts. Within this format, a large, positive value of cost change would be assigned a high score; a large, negative value would be assigned a low score. A \$0 cost change would be assigned some intermediate score. 
The current scoring system in the MEM and RDSs uses only a few, very broad ranges for assigning scores to cost. All projects with an annual avoidable cost greater than $\$ 5 \mathrm{M}$ are lumped together and given the same score-whether the cost is $\$ 5,000,001$ or $\$ 10,000,000$. The scale could be modified to provide narrower cost ranges, or it could even be a continuous scale.

Better resolution in the cost scale could provide for better budget allocation decisions. The weight given to cost consideration is relatively small compared to the weight given to other categories, such as safety, health, mission impact, and so forth. This means that the score values for costs are numerically small compared to the potential for the other considerations. The score associated with a likely loss of life is hundreds of times larger than the score associated with a few million dollars in cost. This weighting is probably appropriate. However, for a well-run site, the chances of loss of life are very small. In contrast, the likelihood of positive or negative costs are essentially certain-they are highly predictable compared to other issues under consideration. The scores for serious safety and health consequences are essentially multiplied by their likelihood. Therefore, their actual contribution to the calculated benefit is small. In many cases, at well-run sites, the financial consideration for choosing between alternatives will dominate simply because managers will generally not consider proposed projects that have a high likelihood of safety problems. In these cases, enough resolution must be built into the scales for financial issues to provide a clear distinction between proposed activities in terms of their costs.

\section{Revise Weight for the Mortgage Reduction Category}

The RPM assigns a set of weights to each of the categories and to the levels of impact within each category. The appropriate weight for a category depends on how that category is defined and the range of levels that are defined. If the category for Mortgage Reduction is modified as recommended here, its weighting should be recalibrated. ${ }^{4}$

\section{Revise the Budget Allocation Method}

The budget allocation procedure in the RPM should be modified so that it will produce a more nearly optimal allocation. Proposed activities should be ranked according to benefit/cost. If the changes recommended above are made to the scoring categories, the benefit can be computed by subtracting the RPM score after the activity is implemented from the RPM score for before the activity is done.

\section{Apply Evaluation to Discretionary Activities}

Pollution prevention activities are discretionary activities that tend to improve the operations at a site, but they are not essential to the operation of the site. To be evaluated appropriately, they should be evaluated with comparable activities. The first step in using a decision tool to establish a budget for discretionary activities is the identification of the set of discretionary activities from which a selection is to be made.

Although the CRESP report does not specifically address pollution prevention activities, some of the key conclusions are relevant to the problem of evaluating pollution prevention activities. CRESP (p. 33) suggests dividing potential projects (activities) into three groups: high risk, intermediate risk, and low risk. Pollution prevention activities would typically fall into the low-risk eategory. The primary issues in this category are

\footnotetext{
'See (Keeney, 1976) for discussions on procedures for setting weights.
} 
mortgage reduction and cost management. Activities in this category will often save more money than they cost, and they should free up money in later years, which can be spent to deal with larger problems. Pollution prevention should be compared to these sorts of activities.

\section{Extend the RPMMMM Scales to Include ALARA and "No Impact"}

The current MEM/RPM system does not reward opportunities to go beyond compliance to levels as low as reasonably possible (ALARA). Although compliance must always be met, facilities sometimes benefit from going beyond compliance and reducing emissions to the level that risk approaches zero. Pollution Prevention-type activities considered often go beyond compliance and provide indirect benefits to the facility in terms of better environmental stewardship and satisfying public concern about appropriate environmental management. As shown in Table 1.1, we propose the addition of a lowest category in each of the MEM/RPM consequence criteria. We assume that the lowest levels in the current categories are acceptable in the sense that activities do not violate any regulations or written guidance documents.

Table 1.1. Addition of RPM/MEM Scales for ALARA.

\begin{tabular}{|l|l|l|}
\hline Leve & Description & Score \\
\hline TBD & $\begin{array}{l}\text { The impact from the activity is acceptable under all written } \\
\text { regulations and guidance documents; however, it is not } \\
\text { considered to be As Low As Reasonably Achievable } \\
\text { (ALARA). This would generally be the lowest level in the } \\
\text { current RPM/MEM impact for the category. For example, } \\
\text { "Moderate to low level exposure" for the Public Safety and } \\
\text { Health category. }\end{array}$ & TBD \\
TBD & $\begin{array}{l}\text { The impact from the activity meets all regulations and } \\
\text { written guidance and is considered to be ALARA. }\end{array}$ & TBD \\
\hline TBD & There is no impact from the activity. & 0 \\
\hline
\end{tabular}




\section{Conclusions}

The tools that EM has developed for evaluating activities are a useful start in developing a systematic process for making budgetary and programmatic decisions that are consistent within and between sites. However, we note two shortcomings: the financial aspects of activities are not properly accounted for, and the ranking process proposed by the RPM does not lead to an optimal allocation of resources. Both of the shortcomings affect the evaluation of pollution prevention activities. Such activities are generally not ranked highly (and funded) when, in fact, it would be efficient to do so. We believe that the shortcoming of the existing method can be corrected relatively easily without making major changes to the overall framework.

\section{Section 1 References}

(CRESP, 1996) Peer Review Committee of the Consortium for Risk Evaluation with Stakeholder Participation, Peer Review Of The FY1998 Budget Formulation Process Of The U. S. Department Of Energy Office Of Environmental Management (July 31, 1996).

(DOE, 1995( U.S. DOE Office of Environmental Management, Management Evaluation Matrix Training Package and Reference Material, 1995.

(DOE, 1996) U.S. DOE Office of Field Management, Project Management Prioritization Guide, PMG-30 (February, 1996).

(Keeney, 1976) Ralph Keeney and Howard Raiffa, Decisions with Multiple Objectives: Preferences and Value Tradeoffs (John Wiley and Sons, 1976).

(von Winterfeldt, 1986) Detlof von Winterfeldt and Ward Edwards, Decision Analysis and Behavioral Research (Cambridge University Press, 1986).

(OMB, 1992) Office of Management and Budget, Circular No. A-94: Guidelines and Discount Rates for Benefit-Cost Analysis of Federal Programs (October 29, 1992). This circular is revised periodically and is available on World Wide Web at: http://www.whitehouse.gov/WH/EOP/OMB/html/circulars/a094/a094.html. 


\section{Section 2. \\ Pollution Prevention Case Studies: \\ Definning Hazards and Assessing Relative Risk}

\section{Overview}

This section reviews five pollution prevention case studies. The studies exemplify a range of activities across the DOE complex that are typically funded by the Environmental Management Group 77 (EM-77), Office of Pollution Prevention. The pollution prevention case studies can be categorized into the following three types:

- Waste stream reduction/segregation.

- Process enhancement.

- Process replacement.

For each case study, the existing operation and the pollution prevention options are described briefly in terms of measurable parameters, such as type of activity, waste stream composition, costs, return on investment, resource requirements, and associated significant hazards. Table 2.1 lists the case studies we evaluated and the associated category of pollution prevention activity.

Table 2.1. Pollution Prevention Case Studies.

\begin{tabular}{|clll|}
\hline $\begin{array}{c}\text { Case } \\
\text { Study } \\
\text { No. }\end{array}$ & \multicolumn{1}{c}{$\begin{array}{c}\text { Pollution } \\
\text { Prevention } \\
\text { Category }\end{array}$} & \multicolumn{1}{c|}{$\begin{array}{c}\text { Existing Process } \\
\text { (Before) }\end{array}$} & $\begin{array}{c}\text { Pollution Prevention } \\
\text { Process Option } \\
\text { (After) }\end{array}$ \\
\hline 1 & $\begin{array}{l}\text { Waste stream } \\
\text { reduction }\end{array}$ & $\begin{array}{l}\text { Open burning of HE from } \\
\text { dismantlement }\end{array}$ & $\begin{array}{l}\text { Resale of HE from } \\
\text { dismantlement }\end{array}$ \\
\hline 2 & $\begin{array}{l}\text { Waste stream } \\
\text { reduction }\end{array}$ & $\begin{array}{l}\text { Land disposal of shielding } \\
\text { blocks from } \\
\text { decommissioned building }\end{array}$ & $\begin{array}{l}\text { Reuse of blocks for new } \\
\text { building at required } \\
\text { shielding }\end{array}$ \\
\hline 3 & $\begin{array}{l}\text { Process } \\
\text { replacement }\end{array}$ & Photochemical process & Video-imaging process \\
\hline 4 & $\begin{array}{l}\text { Process } \\
\text { enhancement }\end{array}$ & $\begin{array}{l}\text { Wet chemical process for } \\
\text { removal of radioactive lead } \\
\text { from shielding bricks }\end{array}$ & $\begin{array}{l}\text { Benign CO2 cleaning } \\
\text { process for removing } \\
\text { radioactive lead from } \\
\text { bricks }\end{array}$ \\
\hline 5 & $\begin{array}{l}\text { Waste stream } \\
\text { reduction and } \\
\text { process } \\
\text { replacement }\end{array}$ & $\begin{array}{l}\text { Electroplating conventional } \\
\text { methods }\end{array}$ & $\begin{array}{l}\text { Replacement and } \\
\text { reduction of waste streams } \\
\text { and hazardous materials } \\
\text { via process improvements } \\
\text { and changes }\end{array}$ \\
\hline
\end{tabular}

The purpose of this review is to identify linkages between typical pollution prevention activities and the criteria used by the DOE for evaluating risk and prioritizing budget. The risk categories in the Risk-Based Priority Model (RPM) were used as the evaluating criteria. The evaluation was performed in two steps. First, hazards were evaluated for each activity pair, consisting of the existing "before" activity and the pollution prevention option "after" activity. The type of hazards categories considered are listed in Table 2.2. 
After each activity was assessed for hazards, it was evaluated using six of the criteria categories of the RPM method, which are:

- Public health and safety.

- Site and personnel safety and health.

- Compliance.

- Mission impact.

- Cost-effective risk management.

- Environmental protection.

Table 2.2. Example of the hazard categories indicative of the types found within the DOE complex. (See Appendix A for further definitions of each category.)

\begin{tabular}{|c|c|}
\hline \multirow{12}{*}{$\begin{array}{l}\text { Industrial } \\
\text { Safety and } \\
\text { Health } \\
\text { (Worker } \\
\text { injuries or } \\
\text { death from:) }\end{array}$} & Electrical sources \\
\hline & Motion sources \\
\hline & Gravity-mass sources \\
\hline & Pressure sources \\
\hline & Cold sources \\
\hline & Heat sources \\
\hline & Chemical sources \\
\hline & Radiant sources \\
\hline & Biological sources \\
\hline & Ergonomics \\
\hline & Oxygen deficiency \\
\hline & High energy release \\
\hline
\end{tabular}

Transportation Containment and road hazards
Exposure and

Release to

Workers and

Public

Release to the

Environment
Exposure of operators to hazardous material

Hazardous material release to the environment

Hazardous exposure to the public

Radiation hazard

Criticality

External surface contamination

Soil contamination

Surface and groundwater leakage

Off-gas (gas phase)

Airborne (particulate)

Sanitary sewer 
For the purposes of this evaluation, in which we attempt to rank pollution prevention activities in terms of the conventional risk prioritization methods, we chose to use the RPM method because it has a weighting scheme for ranking consequences and likelihood of occurrence. The study attempts to illustrate how pollution prevention activities rank in this type of priority scheme. Note that the six categories of the RPM we used do not include the extra category for social/economic impacts considered in the EM adaptation of the MEM/MEP.

This analysis observed that, for normal operations and when a relatively safe pollution prevention activity is integrated into a nominally safe operation, the integrated processes have little or no change in hazards and risks. The inherent hazards associated with the addition of pollution prevention activities are small because, as part of the integration, a site strictly enforces safety by administrative and engineering controls imposed by internal regulation and/or statutory requirements.

Pollution prevention activities reduce risks under some circumstances for catastrophic events. It has been observed that pollution prevention activities, such as the substitution of safer material and the reduction of hazardous material, can reduce the types and severity of consequences during events such as catastrophic accidents (external events) or natural phenomena (earthquakes). In many safety analysis reports and environmental impact statements, these events are well documented initiators for various accident scenarios. To implement preventative measures or mitigative barriers commensurate to a catastrophic event, such as an earthquake, would be cost-prohibitive. Pollution prevention activities provide an effective method to reduce the level of protection necessary by reducing the hazard source terms and the expense required to mitigate the consequences.

Consider an example of risk reduction provided by material substitution. Suppose that a flammable material, such as ethanol or isopropyl alcohol, is used as a cleaning agent in a test laboratory. An earthquake occurs, compromising a container that would be adequate under normal conditions. During the earthquake, the material is spilled and an ignition source is present. A fire then occurs, which escalates the hazards to a higher level. The simple substitution of a nonflammable cleaner would have reduced the impact of the spill.

The case studies in this section are a few illustrations of risk reduction by material reduction and substitution. Three of the five case studies show the potential risk reduction from the reduction of hazardous material. Case study 3 eliminates the hazardous materials. Case study 4 changes the composition of the waste from a liquid mixed waste to a solid mixed waste, which is more easily processed and contained. Case study 5 involves solvent replacement and acid reduction, which has the potential for reduced risk to workers and the public as a result of a spill or fire initiated by an earthquake or an external event.

\section{Risk Evaluation in the Absence of Full Risk Assessment}

Many factors, including the time and resources available to perform a classical risk assessment, affect the depth and breadth of the assessment. Depth is the level of detail used to assess tasks (e.g., to what extent tasks are broken down for evaluation). Breadth is the range of initiating-event scenarios used for a risk evaluation, which could include normal operations, accident scenarios, and catastrophic events (such as earthquakes or floods). The level of assessment, in turn, can affect the risk ranking because some risk factor might be overlooked. When a finer hazard screening is performed, significant risk reductions may be found by reviewing the less obvious peripheral activities of each task, 
which may have secondary effects. Secondary effects are typically uncovered only during event scenario development using a fault-tree or event-tree analysis.

We considered a coarse evaluation method to be sufficient to demonstrate the characteristics of the RPM method. For illustrative purposes, assumptions were made using input from subject-matter experts to analyze the existing and new pollution prevention activities and to identify the most significant risk contributors.

The seven process steps for our coarse analysis were:

1. Identify and describe the before and after activities for each case study.

2. Document hazards for before and after activities using hazards screening.

3. Develop accident worse-case hazardous scenarios based on normal, off-normal, and abnormal conditions.

4. Use a coarse screen to pair each of the six RPM categories with a hazardous scenario to evaluate risk. The scenarios were documented in table form.

5. Determine the conditions for the selected scenario to establish the likelihood of occurrence and severity of consequences. Ranking values were documented in table form.

6. Assign RPM ranking values to each case study based on the above descriptions.

7. Compare before and after risk rankings to evaluate the net ADS risk reduction score for each case study. 


\section{Hazard Screening and RPM Evaluation Method}

We used two key steps to evaluate hazards for each activity:

1. First, we identified the types of hazards associated with the activity and the associated RPM category. The "before" and "after" activities for each case study were evaluated in terms of two hazards categories:

- Those identified hazards associated with normal and routine operations.

- Those hazards identified as postulated accident events in a Safety Analysis Report, the Environmental Impact Statement/Environmental Impact Report, and other facility safety documents.

2. Second, we evaluated the possibility that the activity would result in an undesirable consequence based on past occurrences for similar operations, or using subject-matter expert opinion.

A primary goal for hazard analysis is to ensure that the full range of possible hazards, such as those listed in Table. 2.2, are identified for all modes (normal mode, abnormal mode, and natural phenomena) that could occur during pollution prevention operations. Such analysis should be done prior to the method of assessing risk using the RDSs. A hazard analysis is used to document the results of a qualitative hazards assessment and is an effective method of collecting, documenting, and evaluating the roll-up of the technical information provided by participants (subject matter experts). In many cases, we made assumptions about the existence and severity of a hazard on the basis of comparisons by risk experts with similar activities and their risk contributors. The hazard list in Table 2.2 was applied to each case study activity, and the hazard modalities were summarized in subsequent tables.

Our hazards/risk screening and evaluation did not require that every individual hazard source or initiating event be detailed to determine whether it resulted in an undesired RPM consequence. It has been shown that time and resources can be significantly reduced by inverting the conventional risk-analysis process and identifying the hazard sources and consequences. Thus, we used an inverse analysis process starting with the broad hazard categories with consequence of interest, and we determined which events could cause that consequence.

For example, a standard hazard analysis would define a high-voltage electrical source as a hazard with unspecified consequences. To determine the consequences, it would typically be necessary to perform a fault- or event-tree analysis to trace all the possible safety consequences, such as electrical shock to a worker, or ignition source for an explosive gas. The approach used here first identifies an undesirable consequence, such as electric shock, and then identifies all the sources (such as activities or equipment) that could cause the shock. The process is repeated for each RPM consequence. For a risk value, a quantitative risk would typically be based on the probability of an undesired occurrence. In our case, a qualitative assessment was based on the number ofhazards present. 
For each case study, we begin with a description of the "before" and "after" activities. The hazard source activities are then summarized in a table identifying each type of hazard, the consequences of each hazard type, and the hazard source with respect to the before and after scenario. Following this table, we discuss how the hazards were translated into actual consequences and the likelihood of occurrence. Finally, a risk ranking table identifies the ranking of each before and after scenario.

The RDSs stipulate that a single scenario needs to be used; however, such an approach does not accommodate the inherent differences in criteria for each separate category of the RPM. Instead of a single scenario for the rankings, we considered several scenarios and selected the most significant ones for a specific consequence category to evaluate the ranking of that category. The selected scenarios are summarized in the hazard discussion and ranking tables for each case study.

The list of some possible hazardous consequences were derived from a diverse set of conditions, including operator tasks, process equipment, and chemicals and materials used. For any given activity, it is possible to generate several different accident and process scenarios that could result in a hazardous consequence based on human error, equipment failure, mitigation barrier failure, or natural phenomena or external events. Similarly, the rankings for severity and likelihood are not based on any single accident or event scenario because our intent was to expose the risks for each category. The method requires examining the full spectrum of hazards and consequences; limiting the assessment to one scenario would not accomplish that objective.

Some special considerations are necessary to rank the risk reduction score using the separate scenarios and categories in the RPM. For the categories of safety, compliance, or mission or environmental impact, it was possible to readily identify the hazard conditions and scenarios (examples are listed in the RPM ranking tables) that one could use to assign risk. The hazards are listed for each case study in the tables entitled "Identification and Screening of Existing Hazards." The net risk ranking for each case study was determined by first ranking the hazards identified for the "before" activity and then the "after" activity, and taking the difference.

The exception to assigning a ranking in this fashion is for Cost Effective Risk Management. Here, the issue is that for the before activities, "avoidable costs" are relative to an alternate case where there is little or no loss (e.g., deterioration of infrastructure, inefficiency, etc.). In this category, it may be difficult to identify an avoidable cost for the before condition (except Case Study 2, explained below). The before conditions were assigned the lowest ranking of 0.0015 (RPM category CR-15 and likelihood D) because the avoidable costs were less than the defined threshold. This approach should not significantly change the final value of RPM ranking because the range of risk values is small for pollution prevention. The important value is the net difference between activities costs which then defines the overall prioritization and level of benefit to implement the new activity.

Case Study 2 differs from the other case studies because it is the only one where the avoidable cost was greater than the threshold dollar value of $\geq \$ 25 \mathrm{M}$, with an anticipated savings of $\$ 37.6 \mathrm{M}$. For example, the burial has a know avoidable costs by diversion of resources and money to accomplish the task. 


\section{Case Study 1: High Explosive Disposition}

Before Activity: Open burn

After Activity: Resale

Type: Waste stream reduction/segregation

Cost: TBD, dependent on process configuration

ROI: TBD, dependent on process configuration

\section{Before Activity: Open Burn}

Thousands of kilograms of PBX material are part of a storage and recovery facility at Pantex. The facility currently disposes of chemical high explosives (HEs) reclaimed from dismantlement by burning. The stockpile can be completely disposed of within the next three years through open burn processing. The amount to be burned and, therefore, total emissions will be reduced by $20 \%$ every year. The current burning process at the Pantex site releases into the atmosphere acceptable levels of emission and chemical composition (allowable by state and federal regulations). Trace amounts of tritium in the PBX are considered to be below any health hazard threshold and do not lead to a health concern.

\section{After Activity: Pollution Prevention Option-Resale}

The processing of HE from weapon disposition has been examined for commercial markets. Resale is attractive in that it reduces the need for open burn, and the resale income could be used to subsidize additional process costs. However, due to the classified nature of the $\mathrm{HE}$ generated from weapons dismantlement, additional processing must occur before the HE can be commercially released. Such processing, which is not required for the existing operation (OB/OD), introduces the potential for additional risks in handling and increases the processing cost above that for the conventional operation. 
Table 2.3. High Explosive Disposition Case Study 1. Identification and screening of existing hazards.

\begin{tabular}{|c|c|c|c|}
\hline Hazard Type & Consequences & $\begin{array}{l}\text { Hazard Source } \\
\text { Before Activity } \\
\text { - Open Burn }\end{array}$ & $\begin{array}{c}\text { Hazard Source } \\
\text { After Activity } \\
\text { - Resale }\end{array}$ \\
\hline \multirow[t]{5}{*}{$\begin{array}{l}\text { Exposure and } \\
\text { release to workers } \\
\text { and public }\end{array}$} & $\begin{array}{l}\text { Exposure of operators to } \\
\text { hazardous material }\end{array}$ & $\begin{array}{l}\text { Material handling } \\
\text { contact during } \\
\text { machining and } \\
\text { burning }\end{array}$ & $\begin{array}{l}\text { Material handling } \\
\text { contact during } \\
\text { machining and } \\
\text { reformulation }\end{array}$ \\
\hline & $\begin{array}{l}\text { Hazardous material release to the } \\
\text { environment }\end{array}$ & $\begin{array}{l}\text { Airborne emissions } \\
\text { from burn (currently } \\
\text { in compliance) }\end{array}$ & $\begin{array}{l}\text { Process waste stream } \\
\text { from residual HE } \\
\text { material, and chemical } \\
\text { reprocessing }\end{array}$ \\
\hline & Hazardous exposure to the public & $\begin{array}{c}\text { Airborne plume from } \\
\text { burn }\end{array}$ & - \\
\hline & Radiation hazard & Trace (ALARA) & Trace (ALARA) \\
\hline & Criticality & - & - \\
\hline \multirow[t]{7}{*}{$\begin{array}{l}\text { Release to the } \\
\text { environment }\end{array}$} & External surface contamination & $\begin{array}{l}\text { burning ground } \\
\text { residue }\end{array}$ & $\begin{array}{c}\text { Reformulation and } \\
\text { chemical destruction } \\
\text { residue }\end{array}$ \\
\hline & Soil contamination & - & - \\
\hline & Surface and groundwater leakage & - & - \\
\hline & Off-gas (gas phase) & - & - \\
\hline & Airborne (particulate) & $\begin{array}{l}\text { Burning fumes during } \\
\text { bum }\end{array}$ & - \\
\hline & Sanitary sewer & - & $\begin{array}{l}\text { Chemical processing } \\
\text { and waste water }\end{array}$ \\
\hline & Off-site waste processing & - & - \\
\hline \multirow{12}{*}{$\begin{array}{l}\text { Industrial safety } \\
\text { and health } \\
\text { (Worker injuries } \\
\text { or death from:) }\end{array}$} & Electrical sources & - & - \\
\hline & Motion sources & machining processes & machining processes \\
\hline & Gravity-mass sources & - & - \\
\hline & Pressure sources & - & - \\
\hline & Cold sources & - & - \\
\hline & Heat sources & - & - \\
\hline & Chemical sources & Fumes & Reformulation effluent \\
\hline & Radiant sources & - & - \\
\hline & Biological sources & - & - \\
\hline & Ergonomics & - & - \\
\hline & Oxygen deficiency & - & - \\
\hline & High-energy release & HE detonation & HE detonation \\
\hline Transportation & Road hazards & no off-site movement & off-site transportation \\
\hline
\end{tabular}




\section{Hazard Screening Discussion of Case Study 1}

Both open burn and resale rely on the same demil techniques for HE removal; however, post-processing of the HE differs for each option. This assessment only considers the HE material after it becomes excess HE (after it is removed from a weapon).

Case Study 1 could conceivably be considered a high-risk activity in terms of the probability of an accident or release of undesirable emissions. However, a review of the preliminary hazards in the context of extensive testing and mitigative and administrative controls reduces the risks significantly. The extent of controls and analysis of the process render the burning of HE an acceptable activity because of minimal handling and processing of the material. Furthermore, the emissions from burning stay below regulatory limits. In addition, because of current $\mathrm{HE}$ inventories, there is no reason to exceed the emission levels; in fact, they will be reduced because of reduced inventory. There may be other reasons to eliminate open burning as an option, such as political pressure or reduced emission standards, but at the moment, this is an environmentally acceptable and relatively low-risk alternative.

The Table 2.3 shows that there is relatively little difference in the number of hazards between the two options. In fact, the new option of resale may actually have greater risks because it requires more processing, handling, and generates additional and different material waste streams (processing effluent). A higher risk factor for the resale option arises from the fact that the number of opportunities for an event is higher with increased handling and processing. 
Table 2.4. Basis for Scoring Case Study 1.

\begin{tabular}{|c|c|c|}
\hline \multirow[t]{2}{*}{$\begin{array}{l}\text { Public Safety } \\
\text { and Health }\end{array}$} & $\begin{array}{l}\text { Before } \\
\text { PS-3C } \\
\text { score }=0.3 \\
\end{array}$ & $\begin{array}{l}\text { Source term for public exposure with open burn is the airborne plume. Although } \\
\text { within compliance, emissions may pose a bealth risk. Chance for a health risk is } \\
\text { scored low since emissions are not considered hazardous at the levels released, and no } \\
\text { empirical evidence in the neighboring areas contradict this conclusion. }\end{array}$ \\
\hline & $\begin{array}{l}\text { After } \\
\text { PS-3C } \\
\text { score }=0.3\end{array}$ & $\begin{array}{l}\text { No extensive airborne emissions for resale, but some liquid process wastestreams } \\
\text { result from machining, waterjets, chemical processing. Liquid wastestream would be } \\
\text { released thru sewer, and wastestream materials treated and rendered nonhazardous. }\end{array}$ \\
\hline \multirow[t]{2}{*}{$\begin{array}{l}\text { Site Personnel } \\
\text { Safety \& } \\
\text { Health }\end{array}$} & $\begin{array}{l}\text { Before } \\
\text { SP-6C } \\
\text { score }=1\end{array}$ & $\begin{array}{l}\text { Post-processing of waste HE is minimal, requiring transport to the burning ground, } \\
\text { removal from shipping canister, setup on trays, and remote ignition. No additional } \\
\text { machining or chemical processing of material once removed as part of demil activity. }\end{array}$ \\
\hline & $\begin{array}{l}\text { After } \\
\text { SP-5C } \\
\text { score }=2\end{array}$ & $\begin{array}{l}\text { The process hazards are increased slightly due to additional material handling for de- } \\
\text { classification, reformulation and chemical disposition prior to resale. In addition, } \\
\text { there are increases in the number of operations for post-processing the HE. These } \\
\text { post-process treatment procedures increases likelihood of an undesired occurrence. }\end{array}$ \\
\hline \multirow[t]{2}{*}{ Compliance } & $\begin{array}{l}\text { Before } \\
\text { CO-9B } \\
\text { score }=7.5\end{array}$ & $\begin{array}{l}\text { Current activity is within state and federal compliance and annual emissions are being } \\
\text { reduced as inventory is depleted. If allowable emission are reduced, activity will not } \\
\text { be in compliance. Scoring is based on tighter emission standards in the near future. }\end{array}$ \\
\hline & $\begin{array}{l}\text { After } \\
\text { Co-9C } \\
\text { score } \\
=0.75\end{array}$ & $\begin{array}{l}\text { Resale alternative has the largest impact in this category if emission standards } \\
\text { become more stringent and open burn no longer meets standards. HE resale is a } \\
\text { viable alternate to reduce the HE inventory while meeting standards. The process } \\
\text { stream will be tailored to meet all requirements using one of the many technologies } \\
\text { available. }\end{array}$ \\
\hline \multirow[t]{2}{*}{$\begin{array}{l}\text { Mission } \\
\text { Impact }\end{array}$} & $\begin{array}{l}\text { Before } \\
\text { MI-13C } \\
\text { score = } \\
0.75\end{array}$ & $\begin{array}{l}\text { Activity is part of weapons dismantlement program, but does not prevent the major } \\
\text { program from being completed. A potential negative project impact arises if emission } \\
\text { regulations disallow open burn \& recovered HE cannot be disposed. Current activity } \\
\text { can reduce HE inventory and stay within state and federal compliance. Process is } \\
\text { adaptable if emission standards change slightly. Rate of destruction can be ramped } \\
\text { down to reduce emissions, but if standards tighten, alternate processing must be used. }\end{array}$ \\
\hline & $\begin{array}{l}\text { After } \\
\text { MI-13D } \\
\text { score } \\
=0.0075\end{array}$ & $\begin{array}{l}\text { Resale activity does not have potential negative impact based on the imposing of } \\
\text { more stringent emission requirements. The activity is subject to market demand, but } \\
\text { has more flexibility due to a variety of alternative processing methods, such as } \\
\text { chemical decomposition, etc that can be scaled to take up the difference. }\end{array}$ \\
\hline \multirow[t]{2}{*}{$\begin{array}{l}\text { Cost Effective } \\
\text { Risk Mgmt }\end{array}$} & $\begin{array}{l}\text { Before } \\
\text { CR-15D } \\
\text { score }= \\
0.0015\end{array}$ & $\begin{array}{l}\text { Open burn uses existing facilities with relatively low resource overhead. If open burn } \\
\text { is disallowed, alternate site uses are uncertain. No significant added costs to continue } \\
\text { the process. Potential for incurred avoidable cost to continue the process not apparent; } \\
\text { therefore, the activity is assigned the lowest RPM score. }\end{array}$ \\
\hline & \begin{tabular}{l|} 
After \\
CR-15B \\
score $=1.5$
\end{tabular} & $\begin{array}{l}\text { Resale requires more infrastructure costs than open burn, but there is cost recovery } \\
\text { from commercial sale. HE could be recycled into other defense organizations with } \\
\text { cost savings. ROI is difficult to predict: extent of HE reprocessing depends on end- } \\
\text { user requirements. }\end{array}$ \\
\hline \multirow[t]{2}{*}{$\begin{array}{l}\text { Environmental } \\
\text { Protection }\end{array}$} & $\begin{array}{l}\text { Before } \\
\text { EN-18C } \\
\text { score }=0.2\end{array}$ & $\begin{array}{l}\text { Burn curves provide a detailed analysis of emission rates and constituents. Emissions } \\
\text { are within regulatory allowable amounts and are atmospherically dispersed. Potential } \\
\text { environmental impact is relatively low since there is no potential release of undesired } \\
\text { material and emissions are not considered environmentally harmful. }\end{array}$ \\
\hline & \begin{tabular}{l|} 
After \\
EN-18C \\
score $=0.2$
\end{tabular} & $\begin{array}{l}\text { Resale can require some HE reprocessing and alternate methods to process unusable } \\
\text { material, creating additional wastes streams. Additional processing yields more } \\
\text { opportunities for inadvertent release or contamination, although at a very low level. }\end{array}$ \\
\hline
\end{tabular}




\section{Case Study 2: Beneficial Reuse of LBL Shielding Blocks at Brookhaven}

Before activity: Land disposal of shielding blocks

After activity: Block reuse for new shielding

P2 Category: Waste Stream Reduction/Segregation-Beneficial Reuse

Cost: $\$ 4,200,000$

ROI: $1,300 \%$

\section{Before Activity 2: Burial of Shielding Blocks at Hanford}

The shielding blocks from the Lawrence Berkeley Laboratory (LBL) decommissioned Bevalac facility are considered to be low-level radioactive waste $(20 \mu \mathrm{rad} /$ hour above background). They consist of various shapes and sizes, totaling 19,000 metric tons, including 5,900 metric tons of high-density concrete. The volume of the blocks is about 13,600 cubic meters. The blocks are to be transported by rail to Hanford for burial at the low-level radiation site.

\section{After Activity 2: Reuse of Shielding Blocks at Brookhaven}

This activity consist of the reuse of shielding blocks from LBL at the RHIC, Brookhaven National Laboratory. Approximately $35 \%$ of the blocks will be reused. The remaining shielding blocks will be shipped to Hanford for disposal. 
Table 2.5. Case Study 2 Shielding Block Reuse. Identification and screening of existing hazards.

\begin{tabular}{|c|c|c|c|}
\hline Hazard Type & Consequences & $\begin{array}{l}\text { Hazard Source } \\
\text { Before Activity } \\
\text { - Block Burial }\end{array}$ & $\begin{array}{l}\text { Hazard Source } \\
\text { After Activity } \\
\text { - Block Reuse }\end{array}$ \\
\hline \multirow{5}{*}{$\begin{array}{l}\text { Exposure and } \\
\text { release to } \\
\text { workers and } \\
\text { public }\end{array}$} & $\begin{array}{l}\text { Exposure of operators to } \\
\text { hazardous material }\end{array}$ & - & - \\
\hline & $\begin{array}{l}\text { Hazardous material release to the } \\
\text { environment }\end{array}$ & - & - \\
\hline & Hazardous exposure to the public & - & - \\
\hline & Radiation hazard & (ALARA) & (ALARA) \\
\hline & Criticality & - & - \\
\hline \multirow{7}{*}{$\begin{array}{l}\text { Release to the } \\
\text { environment }\end{array}$} & External surface contamination & - & - \\
\hline & Soil contamination & - & - \\
\hline & Surface and groundwater leakage & - & - \\
\hline & Off-gas (gas phase) & - & - \\
\hline & Airborne (particulate) & - & - \\
\hline & Sanitary sewer & - & - \\
\hline & Off-site waste processing & - & - \\
\hline \multirow{11}{*}{$\begin{array}{l}\text { Industrial safety } \\
\text { and health } \\
\text { (Worker injuries } \\
\text { or death from:) }\end{array}$} & Electrical sources & - & $=$ \\
\hline & Motion sources & Large lifting machine & Large lifting machine \\
\hline & Gravity-mass sources & Moving large blocks & Moving large blocks \\
\hline & Pressure sources & - & - \\
\hline & Cold sources & - & - \\
\hline & Heat sources & - & - \\
\hline & Chemical sources & - & - \\
\hline & Radiant sources & - & - \\
\hline & Biological sources & $=$ & - \\
\hline & Ergonomics & - & - \\
\hline & Oxygen deficiency & - & - \\
\hline Transportation & Road hazards & Large transport trucks & Longer distance \\
\hline
\end{tabular}

\section{Hazard Screening Discussion for Case Study 2: Beneficial Reuse vs Burial}

The reduction of hazardous consequences is a result of the elimination of waste associated with producing new shielding block material. The 35\% of blocks to be sent to Brookhaven reduce the amount to be buried, resulting in a significant reduction in landfill burial costs and any potential environmental impact from land disposal. There is a reduction in likelihood of a hazardous industrial event because the reuse of the blocks eliminates the handling and transport of new blocks for BNL by $35 \%$. 
Table 2.6. Basis for Scoring Case Study 2.

\begin{tabular}{|c|c|c|}
\hline \multirow[t]{2}{*}{$\begin{array}{l}\text { Public Safety } \\
\text { and Health }\end{array}$} & $\begin{array}{l}\text { Before } \\
\text { PS-3D } \\
\text { score }=0.003\end{array}$ & $\begin{array}{l}\text { The only hazard for this activity is radiation from the low level activation of the } \\
\text { shielding blocks. This level is localized and contained in the material. The only } \\
\text { exposure path to the public would be during off-site transportation or loss of } \\
\text { containment or migration. This is a short-term activity so the opportunities for an } \\
\text { public health accident are relatively low, so the likelihood score is low. }\end{array}$ \\
\hline & $\begin{array}{l}\text { After } \\
\text { PS-3D } \\
\text { score }=0.003\end{array}$ & $\begin{array}{l}\text { Hazards to the public are the same as above. The nature of the contamination is low } \\
\text { level, localized, and contained in the material. The only exposure path to the public } \\
\text { is during off-site transportation. This is a short-term activity so the opportunities for } \\
\text { an accident are relatively low, so the likelihood score is low. }\end{array}$ \\
\hline \multirow[t]{2}{*}{$\begin{array}{l}\text { Site Personnel } \\
\text { Safety \& } \\
\text { Health }\end{array}$} & $\begin{array}{l}\text { Before } \\
\text { SP-5D } \\
\text { score }=0.02\end{array}$ & $\begin{array}{l}\text { Radiation hazard sources to workers are low and require no special handling. The } \\
\text { recognized hazards are primarily industrial (motion and gravity mass types) and } \\
\text { could occur during transportation and characterization. This is a short-term activity } \\
\text { so the opportunities for an accident are relatively low, so the likelihood score is } \\
\text { low. }\end{array}$ \\
\hline & $\begin{array}{l}\text { After } \\
\text { SP-5D } \\
\text { score }=0.02\end{array}$ & $\begin{array}{l}\text { No significant change in hazards from the previous activity. Radiation hazard } \\
\text { sources to workers are low and require no special handling requirements. } \\
\text { Recognized hazards are primarily industrial (motion and gravity mass sources). } \\
\text { This is a short-term activity: opportunities for an accident are relatively low, so } \\
\text { likelihood score is low. }\end{array}$ \\
\hline \multirow[t]{2}{*}{ Compliance } & $\begin{array}{l}\text { Before } \\
\text { CO-10D } \\
\text { score }=0.002\end{array}$ & $\begin{array}{l}\text { The burial activity for low level waste is allowed and designed to be within } \\
\text { compliance. }\end{array}$ \\
\hline & $\begin{array}{l}\text { Atter } \\
\text { CO-10D } \\
\text { score }=0.002\end{array}$ & $\begin{array}{l}\text { The beneficial reuse of the shielding blocks is presumed to be well within the } \\
\text { compliance guidance for BNL. }\end{array}$ \\
\hline \multirow[t]{2}{*}{$\begin{array}{l}\text { Mission } \\
\text { Impact }\end{array}$} & $\begin{array}{l}\text { Before } \\
\text { MI-13B } \\
\text { score }=7.5\end{array}$ & $\begin{array}{l}\text { The negative impact would be from the burial of the blocks which would take up } \\
\text { valuable burial resource and reduces the capacity for disposal of material at } \\
\text { Hanford, there would be a } 4250 \text { cubic meter reduction in burial space available.. }\end{array}$ \\
\hline & $\begin{array}{l}\text { After } \\
\text { MI-13D } \\
\text { score }=.0075\end{array}$ & $\begin{array}{l}\text { There is no apparent negative mission impact from the implementation of the } \\
\text { beneficial reuse. The lowest impact ranking is reflected in the score. }\end{array}$ \\
\hline \multirow[t]{2}{*}{$\begin{array}{l}\text { Cost Effective } \\
\text { Risk Mgmt }\end{array}$} & $\begin{array}{l}\text { Before } \\
\text { CR-14A } \\
\text { score }=40\end{array}$ & $\begin{array}{l}\text { This activity is one of } 2 \text { alternatives. Second alternative is the after activity. For this } \\
\text { alternative, total cost for shipping, characterization, and burial is } \sim \$ 41.8 \mathrm{M} \text {. This } \\
\text { will reduce funds for other activities. Potential for incurred avoidable cost to } \\
\text { continue this process is more quantifiable than the other case studies and also meets } \\
\text { the threshold dollar amount of } \geq \$ 25 \mathrm{M} \text {. So in this case a ranking value is assigned } \\
\text { independently. }\end{array}$ \\
\hline & $\begin{array}{l}\text { After } \\
\text { CR-15D } \\
\text { score }=.0015\end{array}$ & $\begin{array}{l}\text { Total for beneficial reuse is estimated at } \$ 4.2 \mathrm{M} \text {. Total avoided waste is } 4,250 \text { cubic } \\
\text { meter of LLW. There is a significant ROI estimated at } \$ 37.6 \mathrm{M} \text {. There is no capital } \\
\text { loss, so the lowest ranking is given. }\end{array}$ \\
\hline \multirow[t]{2}{*}{$\begin{array}{c}\text { Environmental } \\
\text { Protection }\end{array}$} & $\begin{array}{l}\text { Before } \\
\text { EN-17C } \\
\text { score }=2.0\end{array}$ & $\begin{array}{l}\text { Potential for release is due to loss of confinement and migration of material in the } \\
\text { designated burial facility. Release of } L L W \text { has a long-term environmental impact. } \\
\text { The environmental release paths are very limited and any likelihood of a release of } \\
\text { material would be due to a catastrophic natural phenomena which is low likelihood. }\end{array}$ \\
\hline & $\begin{array}{l}\text { After } \\
\text { EN-17C } \\
\text { score }=2.0\end{array}$ & $\begin{array}{l}\text { Reuse reduces or postpones burial hazards by } 35 \% \text {. The severity and likelihood are } \\
\text { not impacted significantly because of the remaining quantities. Future reuse } \\
\text { opportunities would reduce the score to a lower impact and likelihood. }\end{array}$ \\
\hline
\end{tabular}




\section{Case Study 3: Elimination of Photochemical Wastes at LBL Through Digital Imaging Photography}

Before Activity: Wet Chemistry Photography

After Activity: Digital Imaging

P2 Category: Process Replacement

Cost: $\$ 350,000$

ROI: $37 \%$

Before Activity 3: Wet Chemistry Photography

The existing operation at Lawrence Berkeley Laboratory (LBL) uses wet photographic techniques. Potential chemical hazards associated with this operation include irritants from exposure to acids and hazardous waste handling, and treatment of spent photographic solutions containing silver.

\section{After Activity 3: Digital Imaging}

LBL has converted from a wet chemical process involving 1,590 gal of chemical acid waste per year to a digital photo laboratory, which requires no chemicals. The system consists of scanners, computers, workstations, digital cameras, and high-quality printers. The replacement digital system produces no waste. The annual waste reduction is $6,000 \mathrm{~kg}$ of hazardous waste/ year. Additional benefits are increased efficiency of operation, reduced manpower requirements, and improved output quality. 
Table 2.7. Case Study 3 Digital Photography vs Photochemical Processes.

Identification and screening of existing hazards.

\begin{tabular}{|c|c|c|c|}
\hline Hazard Type & Consequences & $\begin{array}{l}\text { Hazard Source } \\
\text { Before Activity } \\
\text { - Wet Chem Photo }\end{array}$ & $\begin{array}{c}\text { Harard Source } \\
\text { After Activity } \\
\text { - Digital Photography }\end{array}$ \\
\hline \multirow{5}{*}{$\begin{array}{l}\text { Exposure and } \\
\text { release to } \\
\text { workers and } \\
\text { public }\end{array}$} & $\begin{array}{l}\text { Exposure of operators to } \\
\text { hazardous material }\end{array}$ & $\begin{array}{l}\text { Acids, corrosives, } \\
\text { irritants, silver metal }\end{array}$ & - \\
\hline & $\begin{array}{l}\text { Hazardous material release to the } \\
\text { environment }\end{array}$ & - & - \\
\hline & Hazardous exposure to the public & - & - \\
\hline & Radiation hazard & - & - \\
\hline & Criticality & - & - \\
\hline \multirow{7}{*}{$\begin{array}{l}\text { Release to the } \\
\text { environment }\end{array}$} & External surface contamination & - & - \\
\hline & Soil contamination & - & - \\
\hline & Surface and groundwater leakage & - & - \\
\hline & Off-gas (gas phase) & - & - \\
\hline & Airborne (particulate) & - & - \\
\hline & Sanitary sewer & $\begin{array}{l}\text { Spill and release of } \\
\text { photochemicals }\end{array}$ & - \\
\hline & Off-site waste processing & $\begin{array}{l}\text { Neutralization of } \\
\text { chemicals }\end{array}$ & - \\
\hline \multirow{11}{*}{$\begin{array}{l}\text { Industrial safety } \\
\text { and health } \\
\text { (Worker injuries } \\
\text { or death from:) }\end{array}$} & Electrical sources & - & - \\
\hline & Motion sources & - & - \\
\hline & Gravity-mass sources & - & - \\
\hline & Pressure sources & - & - \\
\hline & Cold sources & - & - \\
\hline & Heat sources & - & - \\
\hline & Chemical sources & Fumes, irritant, acid & - \\
\hline & Radiant sources & - & - \\
\hline & Biological sources & - & - \\
\hline & Ergonomics & - & Repetitive stress injury \\
\hline & Oxygen deficiency & - & - \\
\hline Transportation & Road hazards & - & - \\
\hline
\end{tabular}

\section{Hazard Discussion of Case Study 3}

Hazards associated with the wet chemistry process are not significant and of low severity. They are predominantly related to chemical exposures during photographic processing and require limited operator contact with modern processes. The health hazards are in the corrosive, irritant category or containment of metals, such as silver residue. The chemical constituents are nonflammable. Although these hazards are eliminated with the introduction of digital photography, there is no significant change in the hazard levels. 
Table 2.8. Basis for Ranking Case Study 3.

\begin{tabular}{|c|c|c|}
\hline \multirow[t]{2}{*}{$\begin{array}{l}\text { Public Safety } \\
\text { and Health }\end{array}$} & $\begin{array}{l}\text { Before } \\
\text { PS-3C } \\
\text { score }=0.3\end{array}$ & $\begin{array}{l}\text { Two primary waste streams could reach the public: } 1590 \mathrm{gal} / \mathrm{y} \text { of acid disposed } \\
\text { as hazardous waste, and rinsewater released thru sanitary sewer. Amounts do not } \\
\text { constitute major exposure risk. There is potential for inadvertent release during } \\
\text { waste processing or transportation, but mitigative barriers reduce accident } \\
\text { impact. Some silver residue in the waste stream could pose additional low-level } \\
\text { hazards. }\end{array}$ \\
\hline & $\begin{array}{l}\text { After } \\
\text { PS-3D } \\
\text { score }=0.003\end{array}$ & $\begin{array}{l}\text { The digital techniques eliminate the potential release of hazardous materials to } \\
\text { zero. The lowest score in this category is given, but it does not truly represent } \\
\text { the low, reduced level of the hazard. }\end{array}$ \\
\hline \multirow[t]{2}{*}{$\begin{array}{l}\text { Site Personnel } \\
\text { Safety \& } \\
\text { Health }\end{array}$} & $\begin{array}{l}\text { Before } \\
\text { SP-6C } \\
\text { score }=1\end{array}$ & $\begin{array}{l}\text { Hazards, primarily from irritants and fumes, are reduced with automated } \\
\text { chemical processes. A fire or earthquake could cause fumes or a spill resulting } \\
\text { in worker contact. Severity is marginal depending on extent and location of the } \\
\text { spill. }\end{array}$ \\
\hline & $\begin{array}{l}\text { After } \\
\text { SP-7D } \\
\text { score }=0.1\end{array}$ & $\begin{array}{l}\text { The injuries sustained may be due to repetitive stress injuries from the increase } \\
\text { of computer use. This type of injury is occurring more frequently as computer } \\
\text { use increases }\end{array}$ \\
\hline \multirow[t]{2}{*}{ Compliance } & $\begin{array}{l}\text { Before } \\
\text { CO-11C } \\
\text { score }=0.01\end{array}$ & $\begin{array}{l}\text { No significant compliance issues for photochemicals. The process used standard } \\
\text { good practices and conforms to ES\&H requirements for storage/handling. } \\
\text { Violations of good and accepted practice would be primarily due to human } \\
\text { error. }\end{array}$ \\
\hline & $\begin{array}{l}\text { After } \\
\text { CO-11D } \\
\text { score }=.0001\end{array}$ & $\begin{array}{l}\text { Any compliance issues concerning the chemical hazards have been eliminated. } \\
\text { There are no new compliance issues as a result of the digital video process. }\end{array}$ \\
\hline \multirow[t]{2}{*}{$\begin{array}{l}\text { Mission } \\
\text { Impact }\end{array}$} & \begin{tabular}{|l|} 
Before \\
MI-13D \\
score $=.0075$ \\
\end{tabular} & There are no significant issues regarding mission impact. \\
\hline & $\begin{array}{l}\text { After } \\
\text { MII-13D } \\
\text { score }=.0075\end{array}$ & There are no significant issues regarding mission impact. \\
\hline \multirow[t]{2}{*}{$\begin{array}{l}\text { Cost Effective } \\
\text { Risk Mgmt }\end{array}$} & $\begin{array}{l}\text { Before } \\
\text { CR-15D } \\
\text { score }=.0015\end{array}$ & $\begin{array}{l}\text { The process generates }-6000 \mathrm{~kg} \text { of hazardous waste per year. The } \\
\text { photochemical process costs on the order of several hundred thousand annually } \\
\text { with waste processing. This amount does not qualify for this category, which } \\
\text { needs to be greater than a } \$ 1 \mathrm{M} \text {. The lowest ranking is given. The potential for an } \\
\text { incurred avoidable cost to continue this process is not apparent; therefore, this } \\
\text { activity is assigned the lowest RPM score to establish the basis for score the } \\
\text { after activity. }\end{array}$ \\
\hline & $\begin{array}{l}\text { After } \\
\text { CR-15D } \\
\text { score }=.0015\end{array}$ & $\begin{array}{l}\text { The activity cost is } \$ 350,000 \text { and total savings (at NPV) over } 5 \text { years is } \\
\$ 877,000 \text {. This amount does not meet the criteria to qualify for this category } \\
\text { which needs to be greater than a } \$ 1 \mathrm{M} \text {, therefore, the lowest score level is used. }\end{array}$ \\
\hline \multirow[t]{2}{*}{$\begin{array}{l}\text { Environmental } \\
\text { Protection }\end{array}$} & $\begin{array}{l}\text { Before } \\
\text { EN-18B } \\
\text { score }=2.0\end{array}$ & $\begin{array}{l}\text { Inadvertent releases of material through the sanitary sewer system are possible } \\
\text { due to human error or accidental drum spill during processing of the acid. } \\
\text { Environmental damage is not extensive because of the relatively small amount. } \\
\text { The toxicity level is also diluted. The presence of silver changes the toxicity to a } \\
\text { more hazardous level. }\end{array}$ \\
\hline & $\begin{array}{l}\text { After } \\
\text { EN-18D } \\
\text { score }=0.002\end{array}$ & There are no significant issues regarding environmental impact. \\
\hline
\end{tabular}




\section{Case Study 4: Argonne National Laboratory Dry-Ice Pellet Decontamination System}

Before activity: Wet chemical decontamination of lead bricks

After activity: $\mathrm{CO}_{2}$ cleaning process for decontamination

P2 Category: Process Enhancement

Cost: $\$ 485,167$

ROI: $149 \%$

\section{Before Activity: Wet-Acid Process for Decontamination}

Argonne decontaminates surface-contaminated lead bricks (low-level radioactive contamination) for reuse or disposal as nonradioactive waste. The amount of contaminated material (assuming that without scrapping, the surface of the entire brick is considered hazardous) is 246 metric tons of mixed LLW. Surface contamination on lead bricks is decontaminated using conventional mechanical and chemical processes, such as sandblasting and scrubbing with rags soaked in acid. This process generates mixed waste and has a high level of potential exposure to the worker.

\section{After Activity: Dry-Ice Decontamination}

The alternative option is the use of dry-ice $\left(\mathrm{CO}_{2}\right)$ pellets to decontaminate the surface. The system is composed of a pelletizer that makes carbon dioxide pellets and a dieseldriven air compressor used to blast the pellets onto the surface (scouring the surface) to be decontaminated. The process is contained in a modified glovebox. The pellets evaporate to $\mathrm{CO}_{2}$ gas, which is released through a controlled ventilation system. The only waste stream is the contaminated debris. 
Table 2.9. Case Study 4. Identification and screening of existing hazards.

\begin{tabular}{|c|c|c|c|}
\hline Haxard Type & Consequences & $\begin{array}{l}\text { Hazard Source } \\
\text { Before Activity } \\
\text { Wet-Acid Cleaning }\end{array}$ & $\begin{array}{c}\text { Hazard Source } \\
\text { After Activity } \\
\text { Dry-Ice Decontam. }\end{array}$ \\
\hline \multirow{5}{*}{$\begin{array}{l}\text { Exposure and } \\
\text { release to } \\
\text { workers and } \\
\text { public }\end{array}$} & $\begin{array}{l}\text { Exposure of operators to } \\
\text { hazardous material }\end{array}$ & $\begin{array}{l}\text { Acid wash and lead, } \\
\text { mixed waste }\end{array}$ & - \\
\hline & $\begin{array}{l}\text { Hazardous material release to the } \\
\text { environment }\end{array}$ & - & $\overline{-}$ \\
\hline & Hazardous exposure to the public & - & - \\
\hline & Radiation hazard & $\begin{array}{l}\text { LLW (ALARA) } \\
\text { Liquid storage }\end{array}$ & $\begin{array}{l}\text { LLW (ALARA) } \\
\text { Solid storage }\end{array}$ \\
\hline & Criticality & - & - \\
\hline \multirow[t]{7}{*}{$\begin{array}{l}\text { Release to the } \\
\text { environment }\end{array}$} & External surface contamination & $\begin{array}{c}\text { Dispersal of lead and } \\
\text { acid, mixed waste }\end{array}$ & - \\
\hline & Soil contamination & - & - \\
\hline & Surface and groundwater leakage & Mixed waste storage & - \\
\hline & Off-gas (gas phase) & acid fumes & $\mathrm{CO}_{2}$ release \\
\hline & Airborne (particulate) & Debris from scrubbing & - \\
\hline & Sanitary sewer & - & - \\
\hline & Off-site waste processing & $\begin{array}{c}\text { Disposal of acid/lead, } \\
\text { mixed waste }\end{array}$ & $\begin{array}{c}\text { Disposal of lead debris } \\
\text { mixed waste }\end{array}$ \\
\hline \multirow{12}{*}{$\begin{array}{l}\text { Industrial safety } \\
\text { and health } \\
\text { (Worker injuries } \\
\text { or death from:) }\end{array}$} & Electrical sources & - & - \\
\hline & Motion sources & - & - \\
\hline & Gravity-mass sources & Moving heavy bricks & Moving heavy bricks \\
\hline & Pressure sources & - & High-pressure jet \\
\hline & Cold sources & - & Cryo-temp $\mathrm{CO}_{2}$ equip \\
\hline & Heat sources & - & - \\
\hline & Chemical sources & Acid fumes & - \\
\hline & Radiant sources & - & - \\
\hline & Biological sources & - & - \\
\hline & Ergonomics & Repetitive stress & - \\
\hline & Oxygen deficiency & local ventilation & $\mathrm{CO}_{2}$ release \\
\hline & High-energy release & - & - \\
\hline Transportation & Road hazards & Disposal of LLW & Disposal of LLW \\
\hline
\end{tabular}

\section{Hazard Discussion of Case Study 4}

The primary hazard reductions in this category are the elimination of mixed waste and the exposure of the worker to hazardous materials. Mixed waste is generated in both cases; however, the before scenario generates caustic, liquid mixed waste, whereas the after option generates only dry mixed-waste debris. In many cases, the liquid form has the potential for more severe consequences in the event of an accident. Therefore, the before option has more severe consequences, and the after option has lower relative risk. 
Table 2.10. Basis for Ranking Case Study 4.

\begin{tabular}{|c|c|c|}
\hline \multirow[t]{2}{*}{$\begin{array}{l}\text { Public Safety } \\
\text { and Health }\end{array}$} & $\begin{array}{l}\text { Before } \\
\text { PS-3C } \\
\text { score }=0.3\end{array}$ & $\begin{array}{l}\text { Exposure from caustic, liquid mixed wastes. LLW. Possible dispersal as part } \\
\text { of waste-stream processing. The mixed waste would have to defeat } \\
\text { containment from an external event from the activity tasks. }\end{array}$ \\
\hline & $\begin{array}{l}\text { After } \\
\text { PS-3C } \\
\text { score }=0.3\end{array}$ & $\begin{array}{l}\text { Solid, dry mixed waste debris. LLW. Possible dispersal as part of waste- } \\
\text { stream processing. The scenario could be inadvertent release or by the failure } \\
\text { of a mitigative barrier }\end{array}$ \\
\hline \multirow[t]{2}{*}{$\begin{array}{l}\text { Site Personnel } \\
\text { Safety \& } \\
\text { Health }\end{array}$} & $\begin{array}{l}\text { Before } \\
\mathrm{SP}-6 \mathrm{~B} \\
\text { score }=10\end{array}$ & $\begin{array}{l}\text { Potential exposure of operators to liquid mixed waste, acid fumes during } \\
\text { scrubbing. Industrial hazards are from moving heavy material, chemical } \\
\text { fumes, etc. }\end{array}$ \\
\hline & $\begin{array}{l}\text { After } \\
\text { SP-6C } \\
\text { score }=1\end{array}$ & $\begin{array}{l}\text { Potential exposure of operators to solid mixed waste debris. LLW exposure if } \\
\text { there is a failure of the glove box }\end{array}$ \\
\hline \multirow[t]{2}{*}{ Compliance } & $\begin{array}{l}\text { Before } \\
\text { CO-10C } \\
\text { score }=0.2\end{array}$ & $\begin{array}{l}\text { Reduction of mixed waste material on-site, allows for easier reuse, or } \\
\text { disposal. Compliance issues are allowable limits of waste storage. }\end{array}$ \\
\hline & $\begin{array}{l}\text { After } \\
\text { CO-10C } \\
\text { score }=0.2\end{array}$ & $\begin{array}{l}\text { Reduction of mixed waste material on-site, allows for easier reuse, or } \\
\text { disposal. Compliance issues are allowable limits of waste storage. }\end{array}$ \\
\hline \multirow[t]{2}{*}{$\begin{array}{l}\text { Mission } \\
\text { Impact }\end{array}$} & $\begin{array}{l}\text { Before } \\
\text { MI-13D } \\
\text { score }=0.0075\end{array}$ & No mission impact. \\
\hline & $\begin{array}{l}\text { After } \\
\text { MI- 13D } \\
\text { score }=0.0075\end{array}$ & No mission impact. \\
\hline \multirow[t]{2}{*}{$\begin{array}{l}\text { Cost Effective } \\
\text { Risk Mgmt }\end{array}$} & $\begin{array}{l}\text { Before } \\
\text { CR-15D } \\
\text { score }=0.0015\end{array}$ & $\begin{array}{l}\text { The infrastructure requirements are minimal. The process does result in a } \\
\text { reduction of mixed-waste material. The potential for an incurred avoidable } \\
\text { cost to continue this process is not apparent; therefore, this activity is } \\
\text { assigned the lowest RPM score to establish it as the basis for ranking the after } \\
\text { activity. }\end{array}$ \\
\hline & $\begin{array}{l}\text { Anter } \\
\text { CR-15D } \\
\text { score }=0.0015\end{array}$ & $\begin{array}{l}\text { Total Case Study costs is } \$ 485,167 \text {. The projected savings in reduction in } \\
\text { processing and disposal is } \$ 1,210,000\end{array}$ \\
\hline \multirow[t]{2}{*}{$\begin{array}{l}\text { Environmental } \\
\text { Protection }\end{array}$} & $\begin{array}{l}\text { Before } \\
\text { EN-17C } \\
\text { score }=2 \\
\end{array}$ & $\begin{array}{l}\text { Potential impact during mixed-waste product certification, processing, and } \\
\text { transportation. Any release would be considered significant because of the no } \\
\text { rad added reguirement }\end{array}$ \\
\hline & \begin{tabular}{l|} 
After \\
EN-17D \\
score $=0.02$
\end{tabular} & $\begin{array}{l}\text { Reduced potential for accidental release because solid mixed-waste material } \\
\text { processing is easier. }\end{array}$ \\
\hline
\end{tabular}




\section{Case Study 5: Electroplating Waste Minimization}

Before Activity: Standard plating

After Activity: Environmentally conscious manufacturing

P2 Category: Waste Stream Reduction, Process Enhancement

Costs: TBD

ROI: $\$ 500,000$ annually

\section{Before Activity: Standard Plating Methods}

Standard electroplating methods require the use of acids, vapor degreasing, and the discharge of rinse water to the sewer. The current scenario would continue to use acids for plating and would maintain processes that entail expensive compliance requirements.

\section{After Activity: Environmentally Conscious Manufacturing}

The application of environmentally conscious manufacturing (ECM) methods to electroplating is described in detail in the document UCRL-JC-115709. The after scenario in this case study would substitute or apply the following processes:

- Good housekeeping, including inventory control and changes in operating practices.

- Waste reduction, including material substitution.

- Separation technology enhancement and replacement, including process synthesis and engineering.

- Elimination of cadmium plating and the substitution of zinc-nickel.

- Elimination of hexavalent chromium plating to satisfy air-quality regulations.

- Segregation of cyanide solutions to prevent contamination and reduce costs.

- Elimination of cyanide solutions using noncyanide silver plating, copper pyrophosphate processes.

- Replacement of vapor degreasing with aqueous cleaning processes and water-recycle systems: ultrasonic, soak and electrolytic cleaning, high pressure water.

- Changing rinse practices to save over $3 \mathrm{M}$ gal/y using modified continuous-flow systems at spray stations. Recycling rinse water $(60,000 \mathrm{gal} / \mathrm{y})$.

- Elimination of concentrated acids in the cleaning of aluminum parts.

- Conservation efforts, including reducing solution temperatures during off hours, product return, precious metal recovery, and reducing the volume of silver cyanide solutions. 
Table 2.11. Case Study 5. Standard electroplating vs environmentally conscious manufacturing. Identification and screening of existing hazards.

\begin{tabular}{|c|c|c|c|}
\hline Hazard Type & Consequences & $\begin{array}{l}\text { Hazard Source } \\
\text { Before Activity } \\
\text { - Standard Process }\end{array}$ & $\begin{array}{l}\text { Hazard Source } \\
\text { After Activity } \\
\text { - ECM Process }\end{array}$ \\
\hline \multirow{5}{*}{$\begin{array}{l}\text { Exposure and } \\
\text { release to workers } \\
\text { and } \\
\text { public }\end{array}$} & $\begin{array}{l}\text { Exposure of operators to } \\
\text { hazardous material }\end{array}$ & $\begin{array}{c}\text { Chemical handling } \\
\text { contact during } \\
\text { plating }\end{array}$ & $\begin{array}{c}\text { Reduced or eliminated } \\
\text { material }\end{array}$ \\
\hline & $\begin{array}{l}\text { Hazardous material release to the } \\
\text { environment }\end{array}$ & $\begin{array}{l}\text { Release during fire or } \\
\text { spill }\end{array}$ & $\begin{array}{c}\text { Reduced or eliminated } \\
\text { material }\end{array}$ \\
\hline & Hazardous exposure to the public & $\begin{array}{l}\text { Airborne plume from } \\
\text { fire }\end{array}$ & $\begin{array}{l}\text { Reduced material } \\
\text { available for source }\end{array}$ \\
\hline & Radiation hazard & (ALARA) & - \\
\hline & Criticality & - & - \\
\hline \multirow[t]{7}{*}{$\begin{array}{l}\text { Release to the } \\
\text { environment }\end{array}$} & External surface contamination & Spill of materials & $\begin{array}{c}\text { Reduced or eliminated } \\
\text { material }\end{array}$ \\
\hline & Soil contamination & $\begin{array}{l}\text { Storage or disposal } \\
\text { accident }\end{array}$ & - \\
\hline & Surface and groundwater leakage & $\begin{array}{c}\text { Storage or disposal } \\
\text { accident }\end{array}$ & - \\
\hline & Off-gas (gas phase) & Solvents & $\begin{array}{c}\text { Reduced or eliminated } \\
\text { material }\end{array}$ \\
\hline & Airborne (particulate) & Fumes from fire & - \\
\hline & Sanitary sewer & Release of rinse water & $\therefore$ \\
\hline & Off-site waste Processing & $\begin{array}{c}\text { Solvent and acid } \\
\text { disposal }\end{array}$ & - \\
\hline \multirow{11}{*}{$\begin{array}{l}\text { Industrial Safety } \\
\text { and Health } \\
\text { (Worker injuries } \\
\text { or death from:) }\end{array}$} & Electrical sources & Electrode, current & - \\
\hline & Motion sources & - & - \\
\hline & Gravity-mass sources & - & - \\
\hline & \begin{tabular}{|l|} 
Pressure sources \\
\end{tabular} & - & High-pressure sprayers \\
\hline & Cold sources & - & - \\
\hline & Heat sources & Heated baths & - \\
\hline & Chemical sources & Fumes, acid burns & $\begin{array}{c}\text { Reduced or eliminated } \\
\text { material }\end{array}$ \\
\hline & Radiant sources & - & - \\
\hline & Biological sources & - & - \\
\hline & \begin{tabular}{|l} 
Ergonomics \\
\end{tabular} & - & - \\
\hline & Oxygen deficiency & Chemical fumes & - \\
\hline Transportation & Road hazards & Disposal of chemicals & $\begin{array}{c}\text { Reduced or eliminated } \\
\text { material }\end{array}$ \\
\hline
\end{tabular}


Hazard Discussion of Case Study 5: Standard Electroplating vs Replacement and Reduction of Waste Streams and Hazardous Materials via Process Improvements and Changes

The new option results in a reduction in hazards due to a significant reduction of hazardous materials and wastes. The activities are also modified to reduce the potential for inadvertent release.

Any new hazards that are introduced do not contribute in a significant way to the consequences. The severity of the consequences are reduced with the new activity, but the initiating accidents have not changed; thus, the likelihood remains consistent with respect to the before and after activities.

For example, the modes of emission, such as spills and possible release to the sewer system, are still present. However, several mitigation control levels are put in place to prevent significant releases to the environment and the public during normal operations. Controls may be compromised or bypassed by new migration paths during catastrophic events. In either case, the ranking using the RPM reflects a low delta value. 


\section{Table 2.12. Basis for Ranking Case Study 5.}

\begin{tabular}{|c|c|c|}
\hline \multirow[t]{2}{*}{$\begin{array}{l}\text { Public Safety } \\
\text { and Health }\end{array}$} & $\begin{array}{l}\text { Before } \\
\text { PS-2C } \\
\text { score }=3.0\end{array}$ & $\begin{array}{l}\text { Exposure from liquid waste streams by an external event or natural } \\
\text { phenomena during on-site and off-site storage, processing, and } \\
\text { transportation. }\end{array}$ \\
\hline & $\begin{array}{l}\text { After } \\
\text { PS-3C } \\
\text { score }=0.3\end{array}$ & $\begin{array}{l}\text { Reduced material processed. Releases to the public are through sanitary } \\
\text { sewer, or by a failure of a mitigative barrier, or by human error during } \\
\text { waste processing. }\end{array}$ \\
\hline \multirow[t]{2}{*}{$\begin{array}{l}\text { Site Personnel } \\
\text { Safety \& } \\
\text { Health }\end{array}$} & $\begin{array}{l}\text { Before } \\
\text { SP-5C } \\
\text { score }=2.0\end{array}$ & $\begin{array}{l}\text { Solvents and acids can be splashed or spilled during routine operations. } \\
\text { There is also potential for exposure from liquid waste streams by an } \\
\text { external event or natural phenomena during on-site and off-site storage, } \\
\text { processing, and transportation. }\end{array}$ \\
\hline & $\begin{array}{l}\text { After } \\
\text { SP-6C } \\
\text { score }=1.0\end{array}$ & $\begin{array}{l}\text { Reduced and substituted solvents and acid material to be splashed or } \\
\text { spilled during routine operations. }\end{array}$ \\
\hline \multirow[t]{2}{*}{ Compliance } & $\begin{array}{l}\text { Before } \\
\text { CO- } 11 \mathrm{C} \\
\text { score }=0.01\end{array}$ & $\begin{array}{l}\text { Regulations for chemicals in amounts and types. The risk is if the } \\
\text { regulations for amounts and types of materials used are changed. }\end{array}$ \\
\hline & $\begin{array}{l}\text { After } \\
\text { CO- 11C } \\
\text { score }=0.01\end{array}$ & $\begin{array}{l}\text { Reduced amounts of material. Risk is reduced because of material } \\
\text { replacement. }\end{array}$ \\
\hline \multirow[t]{2}{*}{$\begin{array}{l}\text { Mission } \\
\text { Impact }\end{array}$} & $\begin{array}{l}\text { Before } \\
\text { MI-13C } \\
\text { score }=0.75\end{array}$ & $\begin{array}{l}\text { Mission would be impacted only to the extent that the electroplating } \\
\text { facility supports other mission projects. }\end{array}$ \\
\hline & $\begin{array}{l}\text { After } \\
\text { MI-13C } \\
\text { score }=0.75\end{array}$ & $\begin{array}{l}\text { No change from before. Only impact is the extent to which the facility } \\
\text { supports other mission projects. }\end{array}$ \\
\hline \multirow[t]{2}{*}{$\begin{array}{l}\text { Cost Effective } \\
\text { Risk Mgmt }\end{array}$} & $\begin{array}{l}\text { Before } \\
\text { CR }-15 D \\
\text { score }=0.0015\end{array}$ & $\begin{array}{l}\text { No real loss of capability from loss of facility or during continued } \\
\text { operations. The potential for an incurred avoidable cost to continue this } \\
\text { process is not apparent; therefore, this activity is assigned the lowest RPM } \\
\text { score. }\end{array}$ \\
\hline & $\begin{array}{l}\text { After } \\
\text { CR- 15D } \\
\text { score }=0.0015\end{array}$ & Savings on the order of $\$ 500,000$ per year. \\
\hline \multirow[t]{2}{*}{$\begin{array}{l}\text { Environmental } \\
\text { Protection }\end{array}$} & $\begin{array}{l}\text { Before } \\
\text { EN- 17D } \\
\text { score }=0.02\end{array}$ & $\begin{array}{l}\text { Catastrophic external or natural event could result in unmitigated release } \\
\text { of material to the ground or as fumes during a fire. Effects to the } \\
\text { environment are not irreversible. }\end{array}$ \\
\hline & $\begin{array}{l}\text { After } \\
\text { EN- 17D } \\
\text { score }=0.02\end{array}$ & $\begin{array}{l}\text { Catastrophic event could result in unmitigated release of material to the } \\
\text { ground, or as fumes during a fire. Severity is reduced from the substitution } \\
\text { and reduction of material. Effects to the environment are not irreversible. }\end{array}$ \\
\hline
\end{tabular}




\section{Summary of Case Study Evaluation}

The methodology we employed was intended to provide a realistic approach to risk screening. Although our risk assessment is more qualitative than a formal probabilistic risk assessment, the process we used, when combined with DELPHI techniques (using expert opinion), offers the advantage of quick and cost-effective implementation.

The five selected case studies illustrate a cross-section of pollution prevention activities that may be implemented. From the case studies, we can compare how the RPM scoring method impacts pollution prevention activities and their risk score. The risk score is important because it is one factor that determines whether a project receives funding. The ranking scores determined are considered to be representative of pollution prevention and are accurate to within a few ranking groups. This degree of accuracy (or possible error) in our scoring would not significantly change final conclusions concerning the low ranking given to pollution prevention by the RPM.

Table 2-13 and Figure 1 show how the five case studies compare to one another with respect to the definitions of the RPM consequence categories and using the hazard screening technique outlined previously (Tables 2.3 through 2.12). Figure 2 is a graph of the net RPM risk ranking, which would be used to score the Activity Data Sheets.

Finally, we show how the cost/benefit of pollution prevention activities could be better represented using a modified RPM Cost Effective Risk Management Category scale. Table 2-14 shows the new rankings for each case study.

\section{Evaluation of the RPM Ranking}

Tables 2.4, 2.6, 2.8, 2.10, and 2.12 show the scoring of identified hazard consequences between each of the activities with respect to the six RPM categories we considered: Public Safety and Health, Site Personnel, Compliance, Mission Impact, Cost Effective Risk Management, and Environmental Protection. This section compiles those scores in tables and figures to illustrate the points discussed in Section 1.

The figures provide some insight into the types of hazardous consequences associated with pollution prevention and how they are ranked in the RPM. They also provide a sense of what parameters (hazard type, source term, affected population, etc.) are at issue when assessing the implementation of an activity. An important result is that the RPM tends to rank pollution prevention activities low. In so doing, the process gives a false impression by not attributing merit to such activities.

Figure 1 plots the distribution of RPM values for the combined before and after activities

for a total of 60 RPM score entries (five case studies $\times$ two scenarios $\times$ six RPM consequence categories). The results are grouped into bins: from 0 to $0.01,0.01$ to 1,1 to 5,5 to 10,10 to 50 , and 50 to 3000 . The majority of scoring values are in the lowest bins. On the RPM scale, which ranges from 0 to 3000,59 of the 60 entries received a rank of 10 or less. This result clearly illustrates that, although the activities may actually have considerable merit, according to the RPM, the majority of the activities are ranked very low indeed. 


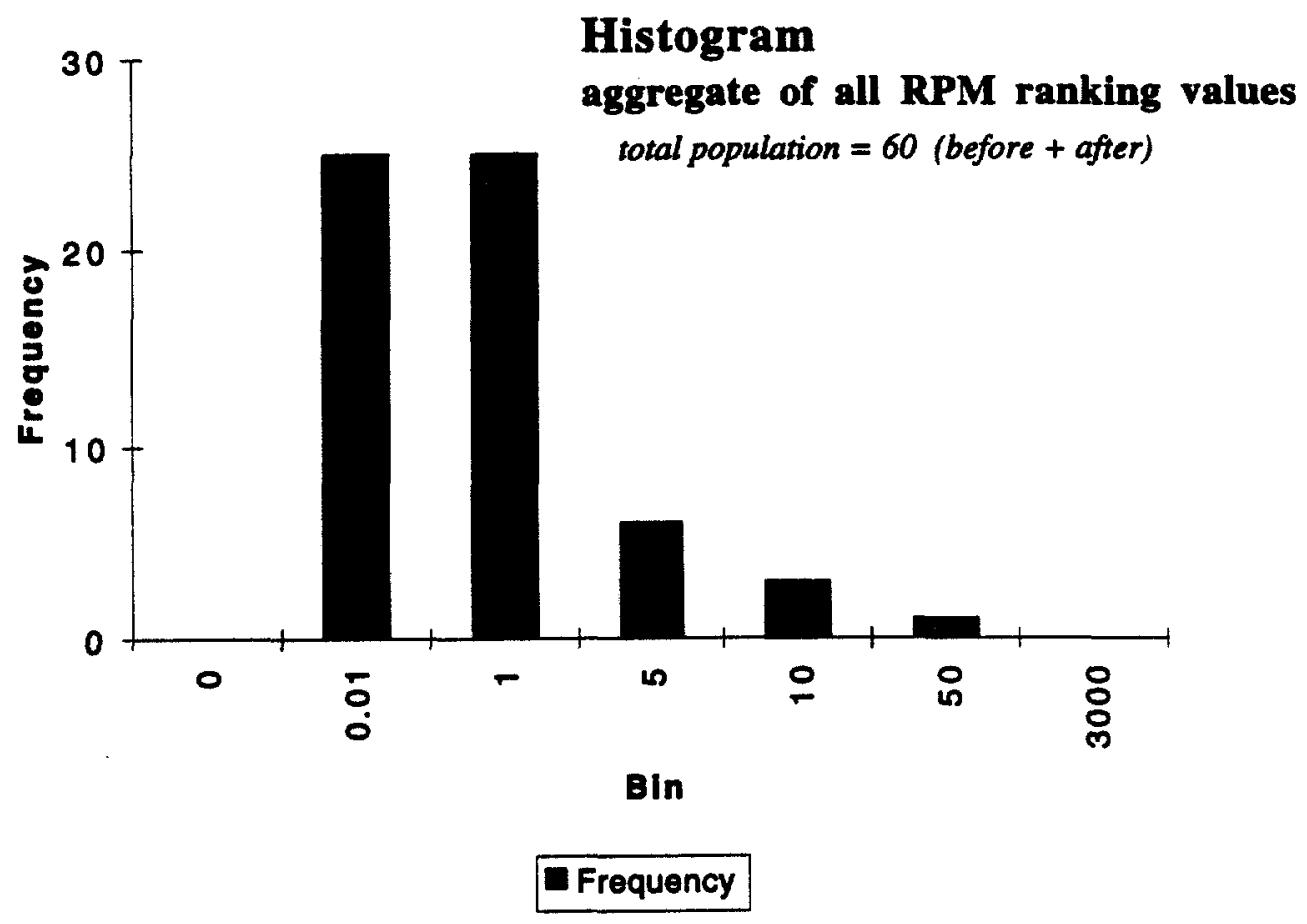

Figure 1. Histogram of RPM rankings values listed in Tables 2.4, 2.6, 2.8, 2.10, and 2.12. The values are all less than 50 with the majority 5 or below. 


\section{Net Risk Reduction}

Table 2.13 assigns a ranking to each case study according to the net change in risk for the before and after options. The data are organized by rows for each of the Risk-Based Priority Model consequence categories. (See Appendix B for a more detailed description of each of the RPM consequence categories.)

Figure 2 is a graph of the roll-up of the difference in rankings. This is the actual net ADS risk-reduction score used to compare the individual case studies in terms of risk reduction by implementation of the new after activity.

Table 2.13 demonstrates that introducing a new option can result in (1) little change in the operational and health risk (rank 0), (2) a positive benefit (rank >0), or (3) additional problems (rank $<0$ ). Case Study 1 is an example of the latter result. Here, a negative value is assigned because resale may slightly increase risk. In contrast, Case Study 2 is an example of a positive benefit. The change in rank of +39.998 is driven by the high return of investment of more than $\$ 37 \mathrm{M}$ and signifies a desirable risk reduction.

Key for Table 2.13.

$\begin{array}{|ll|}\Delta \text { ranking } & \begin{array}{l}\text { Comparison of before and after activities. } \\ \text { A reasonable benefit. The after activity has a positive effect, reflected in a } \\ \text { positive numerical value. This ranking is assigned if there is a beneficial } \\ \text { change in hazardous consequences between the before and after activities. }\end{array} \\ & \begin{array}{l}\text { Negligible or no change in benefit between the options. There is no } \\ \text { substantive change in hazardous consequences between the before and after } \\ \text { activities. }\end{array} \\ & \begin{array}{l}\text { The after activity may create additional hazardous consequences, reflected in } \\ \text { a negative numerical value. This ranking is assigned if there is a negative } \\ \text { change in hazardous consequences between the before and after activities. }\end{array}\end{array}$


Table 2.13. RPM $\Delta$ Ranking of Pollution Prevention Case Studies.

\begin{tabular}{|c|c|c|c|c|c|}
\hline & $\begin{array}{c}\text { Case Study } \\
1\end{array}$ & $\begin{array}{l}\text { Case Study } \\
2\end{array}$ & $\underset{3}{\text { Case Study }}$ & $\begin{array}{c}\text { Case Study } \\
4\end{array}$ & $\begin{array}{c}\text { Case Study } \\
5\end{array}$ \\
\hline Before Activity & $\begin{array}{c}\text { Open burn of } \\
\text { HE }\end{array}$ & $\begin{array}{l}\text { Land dispossal } \\
\text { of shielding } \\
\text { blocks }\end{array}$ & $\begin{array}{l}\text { Photochemical } \\
\text { process }\end{array}$ & $\begin{array}{l}\text { Wet chemical } \\
\text { decontamination } \\
\text { of lead bricks }\end{array}$ & $\begin{array}{l}\text { Conventional } \\
\text { electroplating }\end{array}$ \\
\hline After Activity & HE resale & $\begin{array}{l}\text { Block reuse for } \\
\text { new shielding }\end{array}$ & Video-imaging & $\begin{array}{c}\mathrm{CO}_{2} \text { cleaning } \\
\text { process for } \\
\text { decontamination }\end{array}$ & $\begin{array}{c}\text { Waste stream } \\
\text { reduction and } \\
\text { process } \\
\text { replacement }\end{array}$ \\
\hline $\begin{array}{c}\text { Public Safety and } \\
\text { Health } \\
\text { ARPM Basis } \\
\text { (PS } 1,2,3)\end{array}$ & 0 & o & 0.297 & $\mathbf{0}$ & 2.7 \\
\hline $\begin{array}{c}\text { Site Personnel } \\
\text { Safety \& Health } \\
\Delta \text { RPM Basis } \\
\text { (SP 4,5,6,7) }\end{array}$ & -1 & 0 & 0.9 & 9.0 & 1.0 \\
\hline $\begin{array}{l}\text { Compliance } \\
\text { ARPM Basis } \\
\text { (CO } 8,9,10,11)\end{array}$ & 6.75 & 0 & 0.0099 & 0 & $\mathbf{0}$ \\
\hline $\begin{array}{c}\text { Mission Impact } \\
\triangle R P M \text { Basis } \\
\text { (MI 12, 13) }\end{array}$ & .7425 & 7.4925 & 0 & $\mathbf{0}$ & 0 \\
\hline $\begin{array}{l}\text { Cost Effective } \\
\text { Risk Mgmt* } \\
\text { ARPM Basis } \\
\text { (CE 14, 15) }\end{array}$ & -1.4985 & 39.9985 & 0 & 0 & O \\
\hline $\begin{array}{c}\text { Environmental } \\
\text { Protection } \\
\text { ARPM Basis } \\
\text { (EN 16,17,18) } \\
\end{array}$ & $\mathbf{0}$ & 0 & 1.998 & 1.98 & 0 \\
\hline
\end{tabular}

* This category is analogous to the Mortgage Reduction MEM category.

The risk benefit is given as the difference between rank values for the "before" and "after" activities (before - after = benefit) using the ES\&H Risk-Based Priority Model (RPM). The higher the value, the greater the relative benefit (e.g., the largest benefit of 39.9985 appears in Case Study 2 for Cost Effective Risk Management). 


\section{Pollution Prevention: Low Risk Benefit per RPM}

After applying RPM scoring, all five case studies showed relatively low elimination of hazard consequences. (The highest benefit scored in Table 2.13 for the safety category is only 9 out of a possible 3000 ). We reviewed several categories of consequences, and the delta impact was relatively low, even for catastrophic events.

This result can be attributed to several factors.

- The process reviewed had no real risk.

- The cases reviewed were relatively safe projects because of imposed and regulatory controls.

- The new option provided a only small incremental change to the original operation.

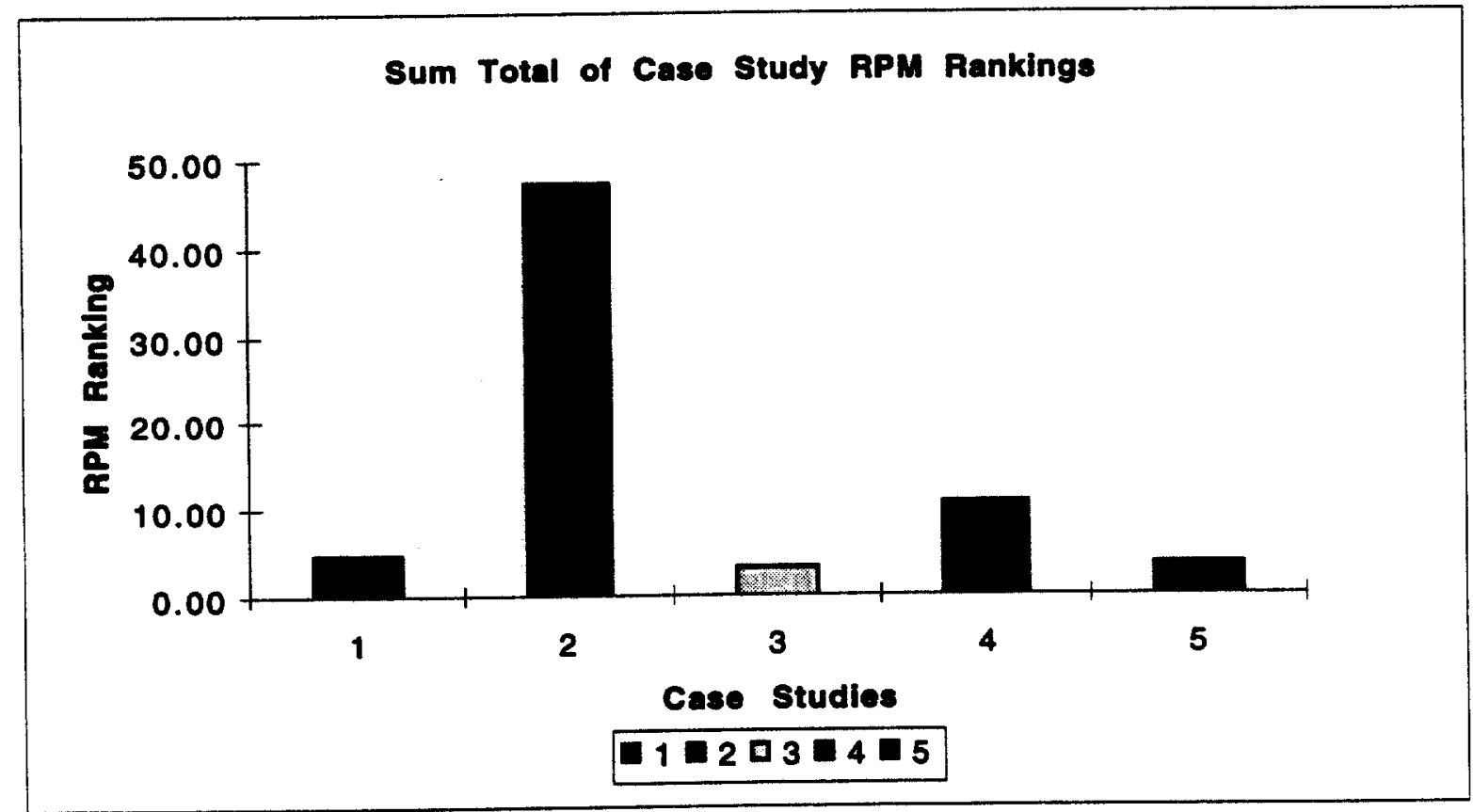

Figure 2. Sum total, for each case study, in the change in ranking for the six RPM categories between the before and after activities. The changes are relative to the before activity (the higher the value, the greater the aggregate benefit of the 6 categories). The highest value for Case Study 2 is driven by the high return of investment (more than \$40M). 


\section{Alternative Cost Scale}

When current cost/benefit scores are used for risk comparisons to other competing activities, the existing scoring system is less likely to favor pollution prevention activities. The current scale for the Cost Effective Risk Management category contains two levels, which fall either above or below $\$ 1$ to $\$ 5 \mathrm{M}$ annually for cost savings/lost of investment. The problem with this current risk scale is that it has a high cost savings threshold, which discriminates against the majority of lower-cost level pollution prevention activities and assigns essentially a zero score.

For example, the RPM scoring of an activity using the existing scale does not acknowledge the inherent value and cost savings for three of the five case studies we have presented. Because these case studies did not meet the minimum $\geq \$ 1 M /$ year requirement, the RPM scales did not reflect any improvement. Such discrimination in scoring is clearly illustrated in Table 2.13 (see Net risk reduction score for the case studies). When our Case Studies 1 through 5 were scored by the RPM, they were given a net cost risk reduction of $-1.4985,39.9988,0,0$, and 0 , respectively (these values are the change for implementing the new "after" activity and replacing the old "before" activity). For Case Study 1, the value of -1.4985 for the resale of HE is due to the initial capital costs required to implement the activity. Only Case Study 2, which involved the reuse of shielding blocks, received a positive score $(+39.9988)$ because it involved the potential savings of $\$ 42 \mathrm{M}$. The score of zero was assigned to the last three case studies because the expected cost savings (return on investments) were, respectively: $\$ 900,000 / 5$ years, $\$ 1,210,000$ one-time savings, and $\$ 500,000$ annually.

The scoring for the RPM category, Cost Effective Risk Management, would better represent the benefit of pollution prevention activities by use of a higher-resolution scale. The scale should score the dollar amount of the expected loss (net cost) or benefit (avoidable cost). Such a scale would provide a linear range of costs using an extrapolation of the existing RPM range and the existing weights to maintain its relationship with the other categories. Proposed activities can result in cost increases or decreases. Since under the RPM system undesirable consequences receive high scores, cost increases would receive a high score and cost decreases would receive a low score. A zero cost change would be given an intermediate score. Instead of the two levels now used for significant and moderate avoidable costs a range of levels from 0 to 320 would be used. As is described below, this scaling is consistent with the existing RPM scales and weights. Such scaling is only one example of a possible approach to enhance the current method, and further refinement would be needed if implemented.

We suggest a revision of the risk scoring system to extend the range for the current values. The range of the scale would extrapolate the range of cost savings from the existing score of 40 for total avoidable cost of $\$ 25 \mathrm{M}$ to a new scoring range of +160 for a $\$ 100 \mathrm{M}$ incremental loss (i.e., $\$ 100 \mathrm{M} / \$ 25 \mathrm{M}=4$ ). The scale should be linear, and the range should reflect the net costs of some projects as well as the savings. The total scale would range from -160 for a net benefit of $\$ 100 \mathrm{M}$ to +160 for a net cost of $\$ 100 \mathrm{M}$ over the lifetime of the activity. For convenience we can offset the score by 160 so that the range is from 0 to 320 , setting the nominal value for no benefit or loss to +160 (e.g., the existing situation would always receive a score of 160 ). The scale would also include the option of basing the scoring on annual cost. Using the same method and scale detailed above, the range for annual cost would be $\$ 10 \mathrm{M}$ annual savings = score 320 , and annual net cost of $\$ 10 \mathrm{M}=$ score 0 . Both scales are shown in Figure 3.

The scoring values using the revised scale in Table 2.14 are derived from the case study's net dollar amount of Cost Savings, or Net Loss whichever is relevant. The dollar amount 
is plotted onto the scale in figure 2.3 and the score is interpolated from the scale range of 0 to 320 . The risk benefit is accounted for in the net dollar amounts required for the revised scale and is equivalent to the original RPM scale (before - after = risk benefit ). For this revised scale the greater the reduction in risk the lower the number is (that is, under RPM, more favorable outcomes receive lower scores).

For an example of annual costs, the cost savings for Case study 5 is $+\$ 0.5 \mathrm{M}$ annually which interpolates to a score of:

$$
160-((\$ 0.5 \mathrm{M} /+\$ 10 \mathrm{M}) * 160)=152 .
$$

For an example of total costs, the cost savings for Case study 2 is $+\$ 37.6 . \mathrm{M}$ total over the life of the activity which interpolates to a score of:

$$
160-((\$ 37.6 \mathrm{M} /+\$ 100 \mathrm{M}) * 160)=100 \text {. }
$$

\section{Ranking on an Annual Costs Basis}

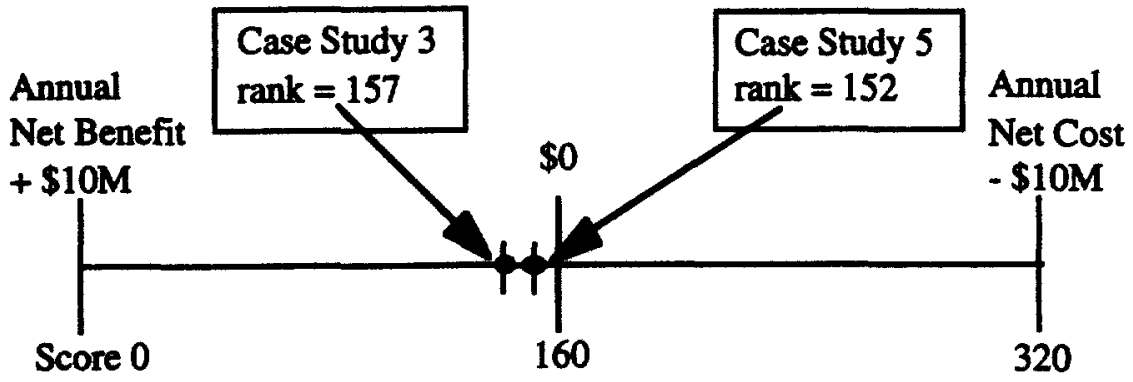

\section{Ranking on a Total Costs Basis}

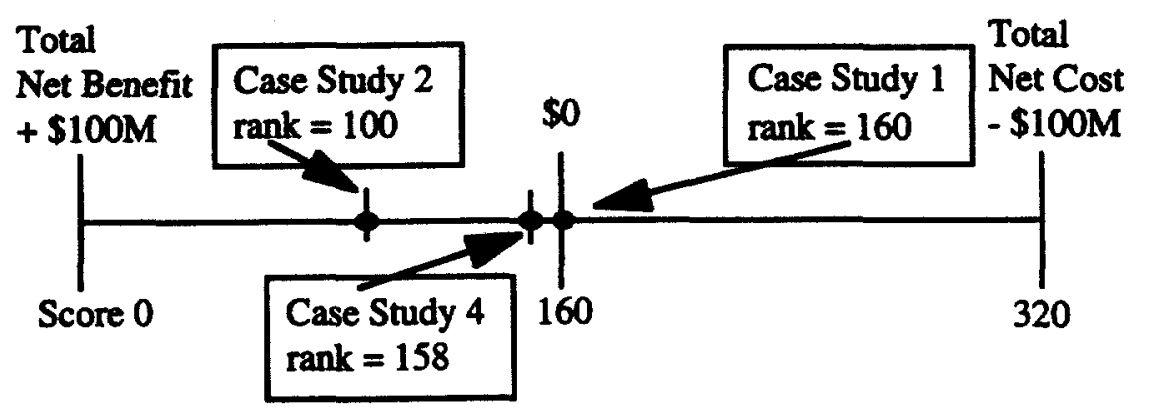

\section{Figure 3. Revised RPM Scale.}

Revised scoring scale for RPM category for Cost Effective Risk Management. The scale is used to evaluate the full range of characteristics of any activity for two different cost scales. Annual and Total. The greater the score the larger the risk. Annual cost saving:

Range from a total net cost of $+\$ 10 \mathrm{M}$ (score $=320$ ) to $-\$ 10 \mathrm{M}$ (i.e., net benefit) (score $=0$ ). An activity with no net cost benefit or loss would be scored in middle of the range (score $=160$ ). Total cost savings:

Range from a total net cost of $+\$ 100 \mathrm{M}$ (score $=320$ ) to $-\$ 100 \mathrm{M}$ (i.e., net benefit) (score $=0$ ). An activity with no net cost benefit or loss would be scored in middle of the range (score $=160$ ).

Case Study 1 is shown as a no net change because actual costs of the "after" resale activity were not available. 
Table 2.14 shows the higher scores for each of our case studies after applying the revised annual cost/benefit scale in Figure 3. The revised risk score values are compared to the original values in Table 2.13. An example of how this revised scale would change the RDS scoring can be shown by comparing how a $+\$ 25 \mathrm{M}$ activity now compares to the case studies. Using the revised scale the risk benefit score for a $+\$ 25 \mathrm{M}$ total savings activity would be scored as 120 . Under the existing risk scoring method described above, four of these activities received 0 credit for their cost savings. This alternative scoring approach gives each activity an appropriate credit for its cost savings..

Table 2.14. Alternate Scale for Cost Effective Risk Management Category. The revised scale is the new scale shown in Figure 3.

\begin{tabular}{|c|c|c|c|c|c|}
\hline & $\begin{array}{c}\text { Case Study } \\
\mathbf{1}\end{array}$ & $\begin{array}{c}\text { Case Study } \\
\mathbf{2}\end{array}$ & $\begin{array}{c}\text { Case Study } \\
\mathbf{3}\end{array}$ & $\begin{array}{c}\text { Case Study } \\
\mathbf{4}\end{array}$ & $\begin{array}{c}\text { Case Study } \\
\mathbf{5}\end{array}$ \\
\hline Before Activity & $\begin{array}{c}\text { Open burn of } \\
\mathrm{HE}\end{array}$ & $\begin{array}{c}\text { Land disposal of } \\
\text { shielding blocks }\end{array}$ & $\begin{array}{c}\text { Photo-chemical } \\
\text { process }\end{array}$ & $\begin{array}{c}\text { Wet chemical } \\
\text { decontamination of } \\
\text { lead bricks }\end{array}$ & $\begin{array}{c}\text { Conventional } \\
\text { electroplating }\end{array}$ \\
\hline After Activity & HE resale & $\begin{array}{c}\text { Block reuse for } \\
\text { new shielding }\end{array}$ & Video-imaging & $\begin{array}{c}\text { CO } 2 \text { cleaning } \\
\text { process for } \\
\text { decontamination }\end{array}$ & $\begin{array}{c}\text { Waste stream } \\
\text { reduction and } \\
\text { process } \\
\text { replacement }\end{array}$ \\
\hline $\begin{array}{c}\text { Cost Effective } \\
\text { Risk Mgmt(1) }\end{array}$ & Score \\
$\begin{array}{c}\text { Absolute Value } \\
\text { Revised Seale }\end{array}$ & 160 & $\begin{array}{c}\text { Score } \\
100\end{array}$ & $\begin{array}{c}\text { Score } \\
157\end{array}$ & $\begin{array}{c}\text { Score } \\
158\end{array}$ & $\begin{array}{c}\text { Score } \\
152\end{array}$ \\
\hline $\begin{array}{c}\text { Cost Effective } \\
\text { Risk Mgmt } \\
\begin{array}{c}\text { ARPM Basis(2) } \\
\text { Revised Scale }\end{array}\end{array}$ & 0 & 60 & 3 & 2 & 8 \\
\hline
\end{tabular}

(1)Values are derived fromFig 3 and are rounded to the nearest integer for illustrative purposes. Scorevalue $=160$ is no net gain or loss. Lower values show greater cost savings. Higher values show greater losses to investment.

(2) Based on modified RPM cost effectiveness scale: $\triangle R P M=160$ (before) - X (after). The higher the value the better the cost savings. 


\section{Section 3}

\section{Outline of Recommended Training for}

\section{Conducting RPM/MEM Assessments}

Using the MEM/RPM framework effectively requires a basic knowledge of risk analysis and probability, as well as skills in defining scenarios, identifying consequences, and assessing likelihoods. The guidance for using MEM/RPM should include knowledge and training in these areas. Although it is possible to provide this instruction in the form of a manual, the material to be presented include somewhat sophisticated concepts of probability and risk analysis. It is our observation that the EM MEM training package provides valuable instruction and information on applying the tools, however, to the untrained risk or decision analyst these concepts are undoubtedly difficult to comprehend without more focused and relevant training to their particular situations. Accordingly, we believe that it is probably more effective to present such material in a course with lectures, and examples, so there is an opportunity for interactive dialogue to discuss methodology.

The overall process can be broken down into the following six steps. A brief description of the type of information considered necessary for personnel required to use these tools for selecting and ranking projects is outlined below.

Step 1: Identify actions that can be taken (including status quo)

Product: a set of possible activities that are intended to improve operations and reduce risks at a site. The set should have a reasonable likelihood of covering all of the objectives at the site and they should be relatively independent of each other.

Key skill: Defining the objectives and concerns at a site, identifying actions to meet them. Grouping actions to account for their interactions.

The definition of "activities" to be evaluated can have a substantial effect on the usefulness of the excercise. We note in Section 1 that the current system focuses on activities rather than on meeting objectives at a site. The training would assist users to more systematically define the site objectives and the factors that hinder accomplishment of those objectives, so that activities can effectively be grouped, ranked and compared. This training segment would focus on the following issues:

- Defining activities to focus on objectives at a site

- Grouping activities appropriately for evaluation

- Defining time frames for activities (e.g., defining "before" and "after" eliminating the ambiguity of "during") 


\section{Step 2: Define scenarios}

Product: A set of scenarios for each proposed activity that represent
sequences of eoents resulting in impacts. The set of scenarios represents
pathways to impacts that may be ameliorated by the activity.
Key skill: Identifying sequences of eoents which cover the range of
plausible occurrences and contribute the most to risk.

Under the MEM/RPM approach, only one scenario is used to evaluate the risk before an activity is implemented and one scenario is used to evaluate the risks after the activity is implemented (the scenarios can be the same or different). Because only one scenario can be used to score all of the impacts, the choice of scenarios can greatly distort the results of the analysis. We recommend that the user be allowed to use more than one scenario when appropraite. Fundamentally, a user must be careful to review a range of possible scenarios and then select the one that best represents the risk reduction from the activity. The training will emphasize the following issues with respect to selecting scenarios that best represent the risks:

- "Routine" vs. "Off-normal":

The scenario under which a proposed activity is evaluated can be one involving either "routine" (normal) operation or an "unexpected" (offnormal) performance of the process to which it is applied or that it involves.

In many cases, it may be preferable to evaluate an activity based on normal operations under which small amounts of material may be released continuously to the atmosphere, rather than a scenario involving a single major offnormal performance releasing substantial material to the environment. The reason, as explained in Section 2, is that the magnitude of the risk is the combined probability of both the event occurring and the consequence or impact resulting, given the event does happen.

Even if the impact is low in the case of routine operation, the likelihood of occurrence of that impact is known to be virtually certain. Alternatively, if the impact is thought to be significant for the offnormal performance scenario, the likelihood of occurrence of that impact may be substantially lower than in the case of normal operation, because the product of the probability of that event occurring is so extremely small. Thus, the risk associated with the normal operation might be larger.

This is particularly relevant to evaluating risks of implemented pollution prevention activities versus the status quo, where eliminating a hazardous material through pollution prevention actions would greatly minimize risk in a catestrophic event. Examples of each of these scenarios would be presented and discussed.

- Use of plausible, supportable scenarios

Only those scenarios that are plausible and supportable empirically (i.e., verifiable by experience, observation, or experimental data that they happened, can happen, 
or nearly happened during assembly, operation, or disassembly) should be given any consideration. Using unplausible scenarios is considered "gaming" and should be recognized, as such.

- Specification of the scenarios for the "after" condition Careful attention should be paid as to whether or not the "After" scenario should differ dramatically from the one used for assessing "Before" implementation of the activity. This decision should be made based on maximizing valuation of the likelihood of occurrence of the particular impacts for the "Before" and "After" time frames, so that generally the smallest difference in reduction of impacts between the "Before" and the "After" situations is obtained. This leads to the most conservative approximation of the reduction in impacts.

\section{Step 3: Identify potential consequences}

Product: A description of the range of consequences that could result from
each of the scenarios identified in the preoious step.
Key skill: Sufficient knowledge of the physical processes involved to
identify the range of consequences that could plausibly result from a
scenario.

A full risk analysis would include all of the consequences that are possible from a scenario and would integrate over them. In the RPM/MEM structure, only one set of consequence levels is allowed. Thus the selection of consequences can have substantial effect on the results. The user needs to have a clear understanding of the range of consequences that can result from an activity.

Step 4: Assess likelihoods of consequences under scenarios

Product: Estimates of the likelihood that a given consequence will arise from a given scenario.

Key skill: Understanding probability computations, and making probability estimates.

In the MEM/RPM framework, the user is asked to develop an estimate of the probability (or frequency) that a given consequence will arise from a given scenario. This requires an estimate of the likelihood of the scenario and an estimate of the likelihood that the consequence will occur, given that the scenario has occurred. The overall likelihood of the consequence is the product of the two.In making the assessments of likelihoods there are a number of opportunities for misconceptions and errors. A user must be versed in the estimation and computation of probabilities to make the required assessments and computations. Guidance will be provided to assist the user:

- Determining the likelihood of consequence

- Determine the likelihoods of impacts, given scenarios 
Like the scenarios, these two probabilities should be supported by experience, observation, or experimental data that they happened, can happen, or nearly happened. The training will review how this information can be obtained or determined by expert opinion.

Step 5: Summarize overall impacts from a potential activity

Product: A composite risk value for an activity computed by summing up the risk values for each category.

Key skill: Overall perspective to ensure consistency in evaluations to yield a reasonable approximate the risk value that would be obtained from a fullscale risk assessment.

A full-scale risk assessment integrates over all scenarios and all consequences. The RPM/MEM approach is an abbreviation that considers only one scenario of events and one set of consequences. This understates risk. Training will assist the user identify a combination of scenario and consequence that gives maximum risk value.

As recommended in Section 1, the training would assign numerical values to the cells in the MEM, similar to the RPM method and demonstrate how these values can assigned.

Step 6: Rank actions and select the preferred ones, within budget

Product: $A$ ranking of all proposed actions and a recommendation as to which should be funded.

Key skill: Correctly assessing the costs of the actions and determining benefit/costs ratio.

We have recommended earlier that activities be ranked based on benefit/cost ratios rather than on absolute improvements in benefits (as is currently recommended in RPM). Making this calculation requires an estimate of the cost of implementing an activity. The user should be versed in techniques for cost evaluation. It often will not be immediately obvious which costs should be included in the cost estimation. Generally the costs considered should be those costs which are constrained since the fundamental theory of the benefit/cost method assumes that one is attempting to efficiently allocate a constrained resource. The training would provide the user with a basic understanding of the technique so as to correctly identify those costs that should be included. 


\section{Appendix A}

\section{Hazard Category Checklist}

Industrial Safety and Health Hazards. Categories for standard ES\&H hazards:

- Electrical sources (high voltage, capacitors, batteries, electrostatics)

- Motion sources (moving and rotating machinery, sharp objects)

- Gravity-mass sources (falling objects, falling, tripping, earthquake)

- Pressure sources ( confined-gas-pressure, chemical reactions, stressed mechanical systems, noise, explosives)

- Cold sources (cryogenic, weather)

- Heat sources (steam, friction, chemical reactions, solar, electrical, spontaneous combustion)

- Chemical sources (corrosives, flammables, toxic, radioactive, carcinogenic)

- Radiant sources (infrared sources, intense visible light, lasers, ultraviolet, magnetic and electric fields, $x$-rays, ionizing radiations, nuclear criticality)

- Biological sources

- Ergonomics (includes operations subject to repetitive stress disorders)

- Oxygen deficiency. (closed vessels, confined spaces, special breathing apparatus)

\section{Exposure and release to workers and public:}

Hazardous and radioactive material exposure and release. Identify the specific population that may be affected by hazardous, radioactive, and mixed waste. Defined according to the accepted levels for the severity of consequence of an operational event, where:

- Exposure of operators to hazardous material

- Hazardous material release to the environment

- Hazardous Exposure to the public (includes exposure of on-site workers)

- Radiation Hazard - includes exposure of the worker, public and environment

- Criticality. This category has unique radiological exposure issues and requirements for standards.

\section{Transportation:}

- Containment is where a loss of containment due to a drum rupture, puncture, or a packaging barrier fails during any handling of packages includes loading, unloading or transporting material

- Road hazard is the loss of containment due to an accident or collision on the road during transport. hazard can then result in a source term.

\section{Release to the Environment:}

Method of hazardous and radioactive material dispersion and contamination. Identifies the mechanism and source term path for the release of hazardous and/or radioactive material to the environment. The metrics of time (amount of time for migration of the radioactive material) and phase (gas, liquid, or solid) of the radioactive source material are assessed for each operation to determine if the method of dispersion and contamination is related.

- External contamination of surfaces by radioactive waste (residual radioactive material from packaging found on containers, packaging, and handling equipment) 
- Soil contamination (radioactive waste material that has been released and has migrated beyond the containment barriers to the ground)

- Surface/ground water leakage (radioactive materials released to the environment via surface water, including rain or treated sewage, or migration to the ground water table)

- Off-gas (the gas phase transfer of radioactive material; includes tritium)

- Airborne (particulate release of TRU particulates generated in a fire)

- Sanitary sewer (monitored waste stream of treated water; includes storm drains). 


\section{Appendix B \\ Description of RPM Consequence Categories \\ (Used in Table 2.1 through Table 2.12)}

\section{Public Safety and Health}

Category Definition: This category impacts the public safety and health, including potential adverse impacts on the safety and health of the off-site population surrounding a facility (three severity levels).

The only case study that had significant positive hazard change in hazard consequences in this category was Case Study 5 - electroplating. This was due to a significant reduction in hazardous liquids used for the electroplating process. The potential exposure paths for the existing activity through a number of spill, fire, or disposal scenarios were all reduced through the new process reduction of hazardous materials.

The other case study processes either did not have a public exposure path, or it was in compliance and maintained within acceptable exposure levels. An example of the first case is Case Study 3 for wet chemistry, and Case Study 4 for the cleaning of lead bricks. Both have no real exposure path of a significant hazardous material to the public. An example of exchange of material paths is Case Study 1 (open burn and resale), where emission modalities are airborne versus waste water, but in both cases within acceptable hazardous material levels.

\section{Site Personnel Safety and Health}

Category Definition: This category impacts the public safety and health, including potential adverse impacts on the safety and health of individuals inside the facility boundary. This includes visitors (four severity levels).

In case study 1 we found that the proposed action could increase the risk rather than decrease it. Additional problems are introduced in terms of hazards. This case study was scored as not as beneficial as the other case studies for this category because the resale option requires additional processing for the HE. The processes are extensive enough that more hazards are introduced to the worker as part of the size reduction and reformulation and consequently more opportunities for an accident.

At the other end of the spectrum is Case Study 5 (electroplating), which is rated as providing a positive benefit. The process removes and reduces the hazardous material to which workers can potentially be exposed. The processes were also modified to be more worker friendly. The combination of changes in the new option significantly changes the opportunity and severity of the consequences during an off-normal event during normal operations, or as the result of a catastrophic event.

\section{Compliance}

Category Definition: Compliance, including failures to comply with laws, regulations, compliance agreements, Executive Orders, DOE Orders, and Implementation Plans for Defense Nuclear Facilities Safety Board (DNFSB) recommendations. Such failure may 
adversely affect the confidence of the DOE or other agencies in the ability of the facility to operate while protecting the public, worker, and environment (four severity levels).

For this category, the impact is best illustrated for Case Study 1 (open burn), where regulatory exposure levels are reduced and open burn can no longer remain in compliance. The implementation of the resale option allows the disposition of HE to continue while elimination of the out-of-compliance condition.

By the same means, the other case studies could also maintain regulatory compliance if exposure and disposal limits were reduced by reduction of waste streams. Examples are the electroplating material substitution of acids, or elimination of the mixed waste stream in the dry-ice cleaning of LLW lead bricks. Resale is still the most significant change, in terms of impact to compliance, because it would be more difficult and expensive to scale the burn process or process the emissions than for the other case studies.

\section{Mission Impact}

Category Definition: This category includes potential adverse impacts on the ability to perform the current and future missions of the facility (two severity levels).

Case Study 2 involves a positive impact on the mission with the reuse of shielding blocks. The reuse allows the blocks to benefit the mission at Brookhaven for reducing costs on the RHIC experiment and providing a necessary safety barrier. The reuse also positively impacts the mission at Hanford by not reducing the waste burial space available.

The other case study options involve similar activities that are effective regardless of meeting the needs of the missions. For example, the disposition of weapon HE can be accomplished with either open burn or resale.

\section{Cost Effective Risk Management}

Category Definition: cost effectiveness including mortgage reduction, which includes potential accidental losses to a facility's capital investment (buildings, equipment) or an existing opportunity for cost savings, such as infrastructure upgrades, management systems upgrades, or improved program development (two severity levels).

An example for this category specifically related to pollution prevention is taken from the RPM training document, as follows:

A facility plans to perform a pollution prevention/waste minimization opportunity
evaluation on one segment of the facility's process and to implement waste minimization
activities based on the findings of the evaluation. Preliminary evaluations have indicated
that the resulting waste reduction would substantially reduce disposal costs. It is
estimated that costs could be reduced by around $\$ 3 M$ per year.

Our Case Studies give a good representation of substantial return on investment in four of the five categories. Case Studies 2, 3, 4, and 5 have substantial return of investments with savings of $\$ 37.6 \mathrm{M} /$ case study duration, $\$ 0.9 \mathrm{M} / 5$ years, $\$ 1.21 \mathrm{M}$ one-time savings, and $\$ 0.5 \mathrm{M} /$ year, respectively. For Case Study 1 , the return on investment between the open burn and resale was not explicitly defined by the site, but facility personnel estimated that it would significantly increase operations cost. The initial evaluation shows they have no significant difference in costs, but resale does offer a substitution of processes if compliance concerning emission standards becomes an issue. 


\section{Environmental Protection}

Category Deînition: Environmental protection includes potential adverse impacts on the ability to perform the current and future missions of the facility (two severity levels).

Case Study 5 has some impact reduction in this category because of the reduction of acids that have a potential migration path through sanitary sewer as a result of some accident or potential release to the environment through a spill.

This category has negligible impact on Case Study 2 (shielding block reuse), and a slightly greater impact for Case Study 3 (photo chemistry) due to accessible release or migration paths to the environment.

In Case Studies 1 and 4, existing activity options have identifiable hazardous and mixed waste materials generated as part of their processes, but have either relatively little hazardous material, as in the case of open burn, or no direct migration or release opportunity, as for the acid wash waste from the lead bricks in Case Study 4. Therefore, there is negligible gain in this category. 


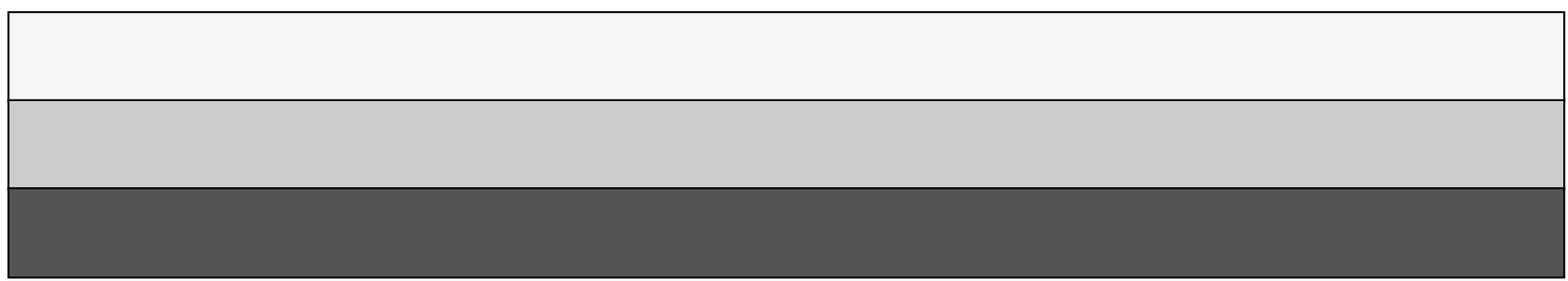

